\title{
The Endocannabinoid System in Glial Cells and Their Profitable Interactions to Treat Epilepsy: Evidence from Animal Models
}

\author{
Jon Egaña-Huguet ${ }^{1,2}$, Edgar Soria-Gómez ${ }^{1,2,3, *(D)}$ and Pedro Grandes $1,2,4, *$ (D) \\ 1 Department of Neurosciences, Faculty of Medicine and Nursing, University of the Basque Country \\ UPV/EHU, 48940 Leioa, Spain; jon.egana@ehu.eus \\ 2 Achucarro Basque Center for Neuroscience, Science Park of the UPV/EHU, 48940 Leioa, Spain \\ 3 IKERBASQUE, Basque Foundation for Science, 48009 Bilbao, Spain \\ 4 Division of Medical Sciences, University of Victoria, Victoria, BC 3800, Canada \\ * Correspondence: edgarjesus.soria@ehu.eus (E.S.-G.); pedro.grandes@ehu.eus (P.G.)
}

Citation: Egaña-Huguet, J.;

Soria-Gómez, E.; Grandes, P. The

Endocannabinoid System in Glial

Cells and Their Profitable Interactions to Treat Epilepsy: Evidence from

Animal Models. Int. J. Mol. Sci. 2021,

22, 13231. https://doi.org/10.3390/

ijms222413231

Academic Editor: Rosaria Meccariello

Received: 22 November 2021

Accepted: 6 December 2021

Published: 8 December 2021

Publisher's Note: MDPI stays neutral with regard to jurisdictional claims in published maps and institutional affiliations.

Copyright: (c) 2021 by the authors. Licensee MDPI, Basel, Switzerland. This article is an open access article distributed under the terms and conditions of the Creative Commons Attribution (CC BY) license (https:// creativecommons.org/licenses/by/ $4.0 /)$.

\begin{abstract}
Epilepsy is one of the most common neurological conditions. Yearly, five million people are diagnosed with epileptic-related disorders. The neuroprotective and therapeutic effect of (endo)cannabinoid compounds has been extensively investigated in several models of epilepsy. Therefore, the study of specific cell-type-dependent mechanisms underlying cannabinoid effects is crucial to understanding epileptic disorders. It is estimated that about 100 billion neurons and a roughly equal number of glial cells co-exist in the human brain. The glial population is in charge of neuronal viability, and therefore, their participation in brain pathophysiology is crucial. Furthermore, glial malfunctioning occurs in a wide range of neurological disorders. However, little is known about the impact of the endocannabinoid system (ECS) regulation over glial cells, even less in pathological conditions such as epilepsy. In this review, we aim to compile the existing knowledge on the role of the ECS in different cell types, with a particular emphasis on glial cells and their impact on epilepsy. Thus, we propose that glial cells could be a novel target for cannabinoid agents for treating the etiology of epilepsy and managing seizure-like disorders.
\end{abstract}

Keywords: endocannabinoid system; glial cells; epilepsy; neuroinflammation

\section{Epilepsy and Neuroinflammation}

Epilepsy is a prevalent disease in our society, being one of the most common neurological conditions affecting 1-3\% of people worldwide [1]. This condition has a high impact on the patient's life, leading to long-term cognitive impairment. Around $70 \%$ of the patients present verbal or episodic memory decline, decreased attention, executive functions or psychomotor issues, and depression [2]. The development of epilepsy involves a variety of molecular modifications leading to aberrant synaptic reorganization. Such changes result in abnormal synchronized neuronal firing and uncontrolled excitability. These events produce spontaneous recurrent episodes of symptoms, known as seizures, which entail excitotoxicity and cell death $[3,4]$. The affected brain regions, mechanisms of action, and pathological manifestations vary depending on the type of seizure-related disorders. For example, idiopathic epilepsies are a result of genetic alterations. On the other hand, acquired epilepsies are caused by traumatic brain injuries or stroke, where epileptic symptoms can arise time before the onset of spontaneous recurrent seizures [5]. The time spent between the first seizure episode and the chronic disease is known as the latent period or epileptogenesis. There, brain alterations occur to end up on an imbalance between excitatory and inhibitory neurotransmission, affecting normal brain functions [6].

Over the last few decades, different studies have shown that inflammation processes driven by glial cell activation and the release of pro-inflammatory cytokines contribute 
to neuronal damage and, therefore, to epileptogenesis, underlying epilepsy-related disorders [7-9]. Furthermore, clinical and experimental research points out that those persistent levels of cytokines in the brain can act as facilitators of cell death. In addition, these molecules could decrease seizure susceptibility or even augment neuronal excitability during the progression of the disease [10-12].

The role of the endocannabinoid system (ECS) in controlling neural network excitability has been the focus of intense pharmacological interest, developing therapies based on the use of cannabinoid compounds for the control of seizures [13-16]. Moreover, ECS protects the brain cells by controlling glutamatergic neuronal excitability through the type 1 cannabinoid receptor $\left(\mathrm{CB}_{1} \mathrm{R}\right)$ activity, the main cannabinoid receptor present in the brain [17-20]. Not only $\mathrm{CB}_{1} \mathrm{R}$ is deeply investigated in the treatment of epilepsy, but also other receptors that also interact with endogenous or exogenous cannabinoids have been postulated as potential targets in the control of seizures. Indeed, in the last ten years, the number of articles published on PubMed in relation to "cannabis and epilepsy" has grown more than 10-fold [21]. Therefore, studying the molecular mechanisms triggered by cannabinoid action could bring novel insights into the understanding of epileptic disorders and related pathophysiological processes.

\section{Etiology and Treatment}

Nowadays, one of the biggest concerns with epilepsy is the high incidence of resistance to current treatments with antiepileptic drugs (AEDs) [16]. In the last decade, different approaches have attempted to prevent seizures and to control them. These treatments, some obtained from pre-clinical studies, ranging from pharmacological therapies based on new compounds such as resveratrol or vitamin E [22,23]; cell therapies rooted on stem cells, interneuron precursor transplants [24-26] or reprograming reactive glia into interneurons [27], and gene therapies such as neuropeptide $Y$ transfection [28,29] to clinical studies in humans, such as modern surgery with laser-induced thermal therapy (LITT); magnetic resonance-guided LITT (MRgLITT) [30,31]; brain stimulation [32,33], or even controlling seizures with diet such as a ketogenic diet or other regimens [34]. Since most AEDs available in the market are only preventing and treating the symptoms instead of acting on the molecular mechanisms, they produce numerous negative side effects that limit their therapeutic use [35-37]. Some treatments increase GABAa receptor activation in the brain, therefore increasing inhibitory tone. Other approaches block sodium or calcium channels to prevent cell depolarization and signal transduction [20]. Hippocampal sclerosis is the most common pathological feature of temporal lobe epilepsy (TLE) in humans that is associated with a significant loss of CA1 pyramidal neurons and prominent reactive astrogliosis [11]. However, the cellular mechanisms promoting abnormal remodeling of neuronal networks in epilepsy are not fully described [38,39]. Consequently, it is crucial to understand such mechanisms in order to elucidate the pathophysiology of the epilepsies, intending to generate novel therapeutic targets useful in seizure control [40].

Human studies have shown the relationship between inflammation, immunity, and epileptic susceptibility in TLE [41-43]. As mentioned before, neuroinflammatory events can potentiate neuronal hyperexcitability and the spread and recurrence of seizures [10,44-46]. Recent reports have demonstrated the involvement of oxidative stress and reactive oxygen species (ROS) in the development of post-traumatic epilepsies. Furthermore, oxidative processes potentiate the effects produced by neuroinflammation itself and outline the importance of controlling such events in the prevention and control of seizures [47]. Therefore, manipulating inflammatory signaling cascades also constitutes a complementary therapeutic approach for treating epilepsies [48]. For instance, some of the pro-inflammatory molecules that have been linked to epilepsy, and thus could contribute to the progression of seizures and epileptogenesis, are cyclooxygenase-2 (COX-2), prostaglandin receptor $\mathrm{EP}_{2}$ $\left(\mathrm{PGEP}_{2}\right)$, interleukin $1 \beta$ and 6 (IL-1 $\beta$, IL-6), transforming growth factor $\beta$ (TGF $\beta$ ), or tumor necrosis factor $\alpha(\mathrm{TNF} \alpha)$, among others $[49,50]$. 
Up to date, most research on epilepsy has been devoted to the study of neuronal mechanisms. However, in the last decade, new reports have focused on non-neuronal cell contributions to the development of the disease [8,51-55], namely glial cells that sustain neurons by different mechanisms [56]. A wide range of glial cell-driven modifications occurs during epileptogenesis, including neuroinflammation [57] and changes in brain architecture $[8,58,59]$. In this sense, astrocytes and microglia deserve special attention since their intrinsic roles in tissue maintenance and repair might be critical in epilepsy development. Thus, future research should consider these cells as essential mediators in the disease, highlighting a new therapeutic target to treat seizure disorders [60,61]. Oligodendrocyte dysfunction also may alter normal brain functioning in several disorders since oligodendrocyte-driven myelination affects axon conduction velocity and signal propagation timing, having a direct impact on neuronal and glial communication. [56]. Nevertheless, although the oligodendroglial participation in epilepsy is so far limited, these glial cells could represent new targets for cannabinoid-based treatments of other brain disorders [62].

\section{ECS on Epilepsy}

The plant Cannabis sativa has been used as an antiepileptic drug [63], although the great variability in patients' response and the psychoactive effects are limiting factors in its application. Although some plant-derived cannabinoids are being employed together with AEDs in seizure control, possible long-term effects that could reduce the antiepileptic action or even aggravate the seizures are the main limitations for the clinical use of cannabis $[15,16,64,65]$. Several reviews have compiled the effects of different cannabinoid compounds on various models of seizures in rodents $[20,66-69]$ and in patients with different epileptic disorders [70,71].

$\mathrm{CB}_{1} \mathrm{R}$ activation has been described to be protective against excitotoxicity $[17,18]$ and brain injury [72]. To this extend, neuronal $\mathrm{CB}_{1} \mathrm{R}$ expression is altered and reorganized in several models of TLE [73-78]. Apart from being located in neurons (principal and interneurons) [79] and neuronal subcellular compartments and organelles such as mitochondria [80-86], $\mathrm{CB}_{1}$ Rs are localized in glial cells such as astrocytes and oligodendrocytes although to a much lower extent [85-88], where it modulates synaptic transmission and plasticity [89-91]. Interestingly, $\mathrm{CB}_{1} \mathrm{Rs}$ are also in astrocytic mitochondria, where they regulate astroglial glucose metabolism and social interactions $[84,92,93]$. Moreover, relatively low $\mathrm{CB}_{1} \mathrm{R}$ mRNA has been detected in cortical microglia of newborn rats $[87,94-96]$. On the other hand, $\mathrm{CB}_{2} \mathrm{R}$ is mostly localized in microglia and macrophages [97-99], and some reports have shown $C_{2} R$ in neurons [100-102]. Although $C_{2} R$ expression in the $\mathrm{CNS}$ is very restricted compared to $\mathrm{CB}_{1} \mathrm{R}$, its upregulation in response to different harmful stimuli $[102,103]$ plays active functions in neurological processes, such as nociception, drug addiction, or neuroinflammation $[104,105]$. Likewise, several studies show that $C_{2} R$ participates in neuroprotection in different models of epilepsy and excitotoxicity [106-109].

In addition, endogenous (eCBs) and exogenous cannabinoids interact with other receptors [110-112] that could directly influence the development and progression of epilepsy. Among these receptors, G-protein coupled receptor 55 (GPR55) [113], nuclear peroxisome proliferator-activated receptor alpha (PPAR $\alpha)[114,115]$, transient receptor potential vanilloid type 1 (TRPV1) [114,116,117], or abnormal cannabidiol receptor (abnCBDR) have been postulated and are currently recognized as cannabinoid-receptors [118].

\section{Review Statement}

Cannabinoid compounds elicit anti-inflammatory and neuroprotective responses against brain insults $[119,120]$. Glial malfunctioning can cause a hypersynchronous-like state and hyperexcitability, together with maintained inflammatory alterations that can promote epileptogenesis and provoke seizures [8]. The activation of $C_{1} R$ and $C_{2} R$ in glial cells exerts neuroprotection by increasing anti-inflammatory and decreasing proinflammatory cytokines, among others [121-123]. In this work, we review the state of 
the art of cannabinoid effects on glial cells and their impact on neuroinflammation and epileptic disorders.

\section{Microglia and ECS in Epilepsy}

\subsection{Microglia}

Microglial cells respond rapidly to pathological events occurring in the surrounding that lead to their activation and changes in their normal functioning. Thus, these glial cells express pattern recognition receptors (PRR), viral receptors, or toll-like receptors (TLR) on their surface [124] that allow them to detect signals from other cells and environmental states in order to sense very subtle changes induced by lifestyle-related factors (cognitive stimulation, exercise, diet, stress) [125,126]. Microglial activation includes migration, morphological changes, and proliferation, depending on the polarization or phenotype triggered. Hence, microglia states can shift from resting M0 to activated pro-inflammatory M1 or anti-inflammatory M2 [127]. Furthermore, these modifications can promote interactions with neurons and astrocytes, causing a general neuroinflammation and brain homeostasis alteration [128-133].

On the other hand, microglial cells are able to release several molecules involved in neuroprotection [134-136]. Thereby, microglia could release endocannabinoids, regulating synaptic transmission and plasticity through different mechanisms [133,137,138]. For instance, anandamide released by primary microglia activates $C_{1}$ Rs at GABAergic interneurons reducing inhibitory synaptic transmission $[133,137]$. Therefore, the ECS in microglia could be a promising target in the control of brain excitability.

\subsection{Microglia and Inflammation in Epilepsy}

The participation of microglia in modulating neuronal networks under seizure conditions is not fully understood [52]. Thus, some studies have linked microglia to the inflammatory constituent of the disease. In contrast, others have reported a worsening of the disease's progression after the genetic ablation of microglial cells, having a negative impact on both behavior and brain activity as well as on the neurodegeneration triggered after the status epilepticus [139]. In animal models, either chemoconvulsants or electrical stimulation induce seizures and status epilepticus, eliciting brain modifications that lead to neuronal hyperexcitability [52]. Those changes are accompanied by microglial activation in specific brain areas and the release of inflammatory mediators [140,141], which could favor or delay the onset of the disease $[52,57,139]$. Thus, it is proposed that microglial activity supports epileptogenic processes in the brain, contributing to disease development.

\subsection{Microglia and ECS in Epilepsy \\ 4.3.1. Cannabinoid Receptors}

There are pieces of evidence indicating that $\mathrm{CB}_{1}$ and $\mathrm{CB}_{2}$ receptors are expressed in microglia depending on microglial conditions [87]. Thus, microglia hardly expressed (if any) $C_{1} R$ and $C_{2} R$ at resting conditions. In fact, specific $C_{1} R$ antibodies were unable to detect $C B_{1} R$ in microglial cells of the healthy brain. However, $C B_{1} R$ was observed in cultured microglia of several species $[95,104,121,142]$. As to $\mathrm{CB}_{2} \mathrm{R}$, only some mRNA has been detected in healthy brain, suggesting that this receptor is not expressed much in quiescent microglia $[97,143,144]$. In the brain, $\mathrm{CB}_{2} \mathrm{R}$ is expressed in activated microglia in certain conditions. For instance, neuropathic pain increases $\mathrm{CB}_{2} \mathrm{R}$ in microglia of the spinal cord that is not seen in chronic inflammatory pain [145]. There is also an increase in microglial $\mathrm{CB}_{2} \mathrm{R}$ in inflammation [146] and in activated microglia in brain tissue of patients with Alzheimer's disease or multiple sclerosis, mostly at the lesion sites $[147,148]$, in the vicinity of tumors [149], and in activated microglia of a simian model of AIDS dementia [150]. The first attempts to localize $\mathrm{CB}_{2} \mathrm{R}$ in the $\mathrm{CNS}$ in basal conditions failed because $\mathrm{CB}_{2} \mathrm{R}$ could only be seen in pathological conditions, as described before. Nevertheless, the $\mathrm{CB}_{2} \mathrm{R}$ receptor was not only detected in microglia $[104,151]$ but also in neurons $[152,153]$. Altogether, the $\mathrm{CB}_{2} \mathrm{R}$ receptor expression increases in activated microglia as a response 
to certain neuropathological and neuroinflammatory conditions [154]. The activation of $\mathrm{CB}_{2} \mathrm{R}$ in microglia by cannabinoids regulates immune functions in these cells, stimulating microglial proliferation and migration and reducing neurotoxic factors such as TNF $\alpha$ or free radicals [155-159] having lower harmful effects in the microglia at the lesion sites [87].

Endocannabinoid signaling participates in microglial cell polarization (i.e., different active phenotypes) $[99,127,160]$, potentially affecting the development of neurological disorders. Thus, eCBs drive microglia to the neuroprotective M2 or the resting M0 states [161]. Indeed, M0-microglia is involved in several physiological functions, ranging from plasticity modulation to synaptic pruning and neuronal maintenance $[135,162]$. In pathological conditions, eCBs and synthetic cannabinoids could dampen nitric oxide (NO) signaling, ROS production, and pro-inflammatory cytokines released from activated M1 microglia [163-165]. In line with this, $\mathrm{CB}_{1} \mathrm{R}$ directly affects the inflammatory reaction of microglial cells produced by the immune challenge elicited by the lipopolysaccharide (LPS) model, but not on normal physiological conditions. Furthermore, the $\mathrm{CB}_{1} \mathrm{R}$ genetic deletion attached to CX3-CR1 positive cells results in reduced pro-inflammatory cytokine production and illness amelioration in males, but not in females, pointing out a sexual dimorphism of $\mathrm{CB}_{1} \mathrm{R}$ in these cells [96]. Likewise, the AEA analog methanandamide and synthetic cannabinoids (WIN 55,212-2, CP 55,940) reduce the inflammatory response by suppressing IL-1 $\beta$ and TNF $\alpha$ production in the LPS model of neuroinflammation [166], indicating that $\mathrm{CB}_{1}$ Rs can mediate changes in inflammatory responses caused by cannabinoids in disease [95] (Figure 1). In addition, microglial $\mathrm{CB}_{2}$ Rs activation reduces TNF $\alpha$ or free radicals $[155,167,168]$, and AEA-induced $\mathrm{NO}$ decrease is mediated by $\mathrm{CB}_{2} \mathrm{R}$ in microglial cells [163] (Figure 1).

In organotypic hippocampal slice cultures treated with L- $\alpha$-Lysophosphatidylinositol (LPI), a model to study excitotoxicity, activation of GPR55 results on microglial neuroprotection [169]. Interestingly, LPS stimulation has opposite effects on GPR55 expression [163,170]. Furthermore, in LPS-activated microglia, GPR55 antagonists (KIT17, ML193) decrease mPGES-1 and COX-2 without affecting microglial viability [171]. The participation of $\mathrm{CB}_{2} \mathrm{R}$ could not be fully excluded, as the inverse $\mathrm{CB}_{2} \mathrm{R}$ agonist $\mathrm{AM} 630$ also decreases $\mathrm{PGE}_{2}$ levels in a similar manner, suggesting that both GPR55 and $\mathrm{CB}_{2}$ receptors could be mediating the KIT17 effect [171] (Figure 1). In this regard, the $\mathrm{CB}_{2} \mathrm{R}$ selective inverse agonist SMM-189 prevents PGE $_{2}$ and IL-1 $\beta$ increase caused by LPS [172] (Figure 1). Moreover, SMM-189 drives microglial polarization from M1 to M2 state [173,174]. However, the M2 microglial indicator CD206 increases with SR-144528 (a CB 2 inverse agonist), unlike with the selective $\mathrm{CB}_{2} \mathrm{R}$ agonists $\mathrm{HU}-308$ and JWH-133 [175]. Furthermore, the latter up-regulates the MKP-1 signaling pathway in microglia, lessening microglial activation and reducing pro-inflammatory cytokine release [135] (Figure 1).

AEA also promotes microglial M2 state [176], and the genetic $\mathrm{CB}_{2} \mathrm{R}$ deletion in microglial cells disrupts the polarization to M2 phenotype [127]. A recent review [127] summarizes the current knowledge about the role of cannabinoids in microglial polarization in different pathological situations. Altogether, because of their participation in microglial polarization and function, modulation of microglial $\mathrm{CB}_{2} \mathrm{R}$ and GPR55 could have a direct impact on the development of epileptogenesis after an excitotoxic insult. 


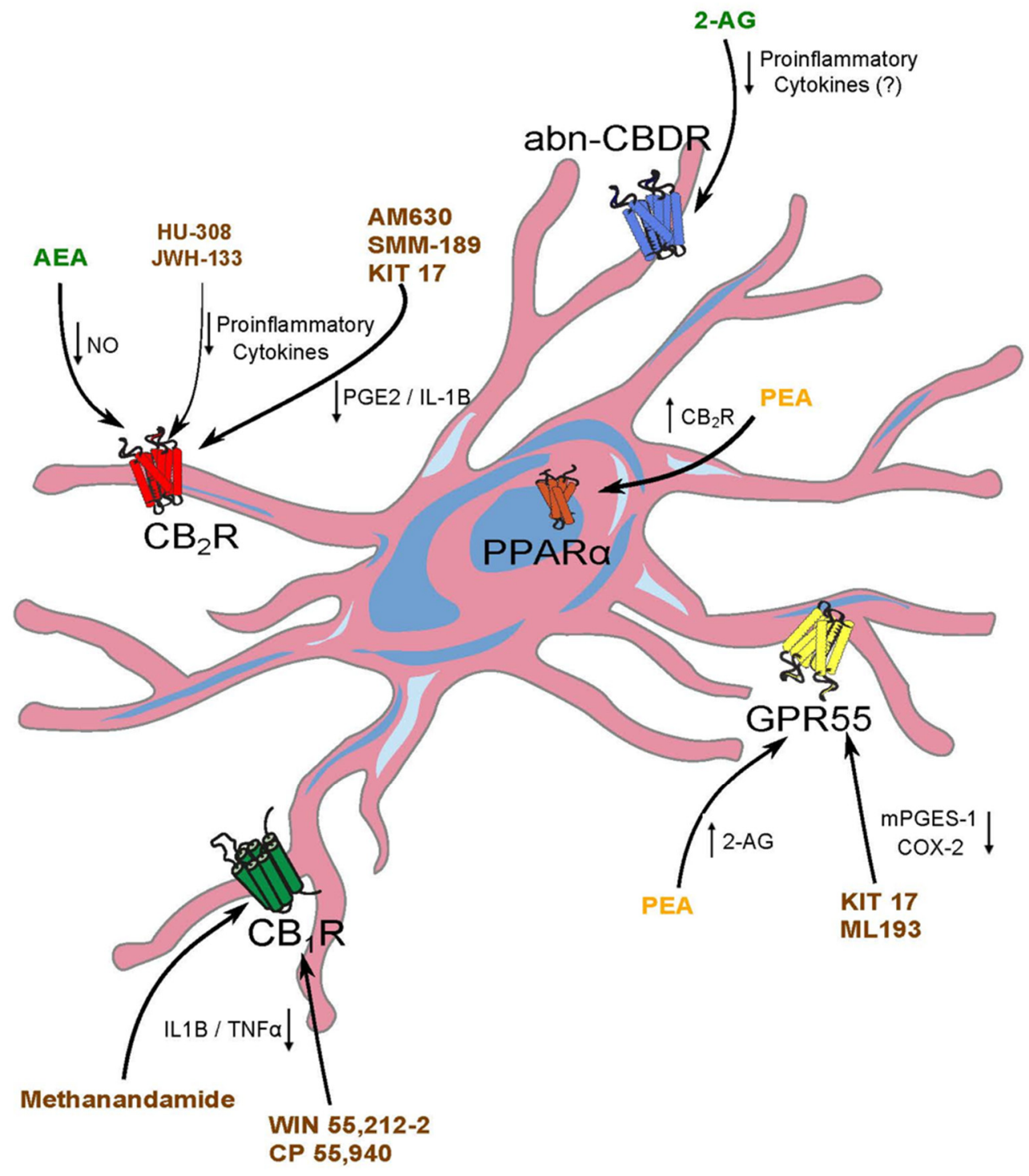

Figure 1. Schematic representation of the interactions of (endo)cannabinoids and synthetic cannabinoid compounds with microglia in the context of epilepsy and neuroinflammation. Endocannabinoids (green) interact with $\mathrm{CB}_{2}$ receptors and other non-classical receptors (GPR55, PPAR and abn-CBDR). Fatty acid amides, such as PEA, interact with non-classical receptors (yellow), while synthetic cannabinoid effects (brown) involve mainly $\mathrm{CB}_{1}$ and $\mathrm{CB}_{2}$ receptors.

\subsubsection{Beyond Cannabinoid Receptors: Other Molecular Targets}

Apart from the canonical cannabinoid receptors, other microglial-expressed molecular targets have been involved in the neuroprotective effect of cannabimimetic compounds. The neuroprotective effects of the endocannabinoid 2-AG have been described mostly related to $\mathrm{CB}_{1} \mathrm{R}$ or $\mathrm{CB}_{2} \mathrm{R}$ activation in several models of neurological diseases $[177,178]$, and 2-AG, N-arachidonoyl dopamine (NADA), and PEA decrease the number of damaged neurons in hippocampal cultures exposed to excitotoxic insults, probably by reducing microglia $[179,180]$. However, 2 -AG also exerts neuroprotection by a non-canonical cannabinoid-like receptor present in microglia [181]. Furthermore, the abn-CBDR that was characterized in blood vessels $[182,183]$ also participates in glial cell guidance by modulating the release of pro-inflammatory cytokines [118] (Figure 1).

PEA is a fatty acid amide compound derived from membrane phospholipids produced on demand that exerts anti-inflammatory effects, probably through PPAR $\alpha$ receptors expressed in microglia $[180,184-187]$. This suggests that cannabinoids acting on microglial PPAR $\alpha$ regulate inflammation elicited by excitotoxic insults. Furthermore, PEA increases 
$\mathrm{CB}_{2} \mathrm{R}$ expression through PPAR $\alpha$ [188] (Figure 1) and 2-AG synthesis via GPR55 activation [189] (Figure 1). Therefore, PEA activity in microglia could engage a complex array of cannabinoid and non-cannabinoid molecular effectors [190]. Thus, it seems that besides classical cannabinoid receptors, other cannabinoid-interacting receptors such as the abn-CBDR or PPAR $\alpha$ could be a promising therapeutic target for future studies. It is important to note that the molecular targets of endocannabinoids and phyto- or synthetic cannabinoids are not necessarily the same. For instance, in an LPS model, while some effects of cannabidiol (CBD) are through PPAR $\gamma$, the PPAR $\gamma$ antagonist GW9662 prevents LPS-stimulated microglial activation [191].

\section{Astrocytes and ECS in Epilepsy}

\subsection{Astrocytes}

Until recent years, astrocytes were seen as bare supportive and structural cells from the CNS, providing maintenance to neurons by connecting them with blood vessels. However, nowadays this concept has totally changed and astrocytes entail a prominent role in brain (patho)physiology. Astrocytes present a morphological structure characterized by complex processes that modulate interactions with other neighboring CNS elements, such as neurons, blood-brain barrier endothelial cells, or other glial cells. By doing this, astrocytes modulate synaptic networks regulating physiological processes spanning from metabolism to behavior [192-195]. For example, astrocytes are crucial for neuronal viability by transporting nutrients from the blood-brain barrier (BBB) in combination with endothelial cells to neurons [196].

Moreover, astrocytes are part of the tripartite synapse [197]. They integrate and process information from the surrounding synapses, mainly due to increased intracellular $\mathrm{Ca}^{+}$ levels and modulation of gliotransmitter release. Thus, they are capable of modulating synaptic plasticity and transmission $[198,199]$. In particular, astrocytes participate in the clearance of neuronal glutamate from the synaptic cleft, helping in cases of hyperactivation and preventing excitotoxicity $[55,200,201]$. Therefore, astrocytic malfunctioning could lead to the occurrence of neuronal disorders such as epilepsy [202].

\subsection{Astrocytes and Neuroinflammation in Epilepsy}

In pathological situations such as hypoxic/ischemic insults, excitotoxicity, or demyelinating diseases, specific morphological, molecular, and functional changes occur in astroglia that might be crucial in preserving CNS functioning. The impact of those changes on neurons is far from being homogenous, varying in a context-specific manner from adaptive responses to harmful mechanisms that can aggravate or even cause some neurological disorders [203].

Astroglia has been postulated as a potential target for treating epileptic disorders. In particular, the control wielded by astrocytes in the balance between GABA and glutamate is critical in controlling seizures [204,205]. For instance, impaired glutamate reuptake and adenosine metabolism disruption are linked to epileptiform activity $[200,206,207]$. Additionally, astrocytes could regulate epileptogenesis by being involved in BBB breakdown and neuroinflammation [208]. Brain inflammation alters gap junction coupling and $\mathrm{K}^{+}$ buffering, inducing disturbances that are fundamental in TLE [209]. All the previous changes described might be behind seizure intermittence $[208,210]$.

\subsection{Astrocytes and ECS in Epilepsy}

The role of the ECS in epilepsy has been thoroughly studied. However, the specific participation of astrocytic cannabinoid signaling has not been greatly considered, even though their involvement seems more than plausible to occur [211]. Thus, an augmented expression of $\mathrm{CB}_{1} \mathrm{Rs}$ in astrocytes in the sclerotic rat hippocampus has been reported after three days and four weeks of pilocarpine-induced status epilepticus. Additionally, $\mathrm{CB}_{1} \mathrm{R}$ expression increases in hippocampal astrocytes from patients with refractory TLE and hippocampus sclerosis [212]. In addition, it has been demonstrated that the phar- 
macological blockade of $\mathrm{CB}_{1}$ Rs prevents calcium elevations in astrocytes, and reduces hippocampal epileptiform activity induced by 4 -aminopyridine (4-AP) [213]. This suggests that endocannabinoid-mediated interactions between neurons and astrocytes are necessary for the maintenance of seizures. Furthermore, the anti-convulsant effect of CBD was linked to GFAP decrease in CA1 and CA3 hippocampus, probably due to the reduction in astrocyte hyperplasia [214]. In co-cultured human astrocytes and brain endothelial cells, CBD reduces BBB permeability in a PPAR $\gamma$-dependent manner [215] (Figure 2).

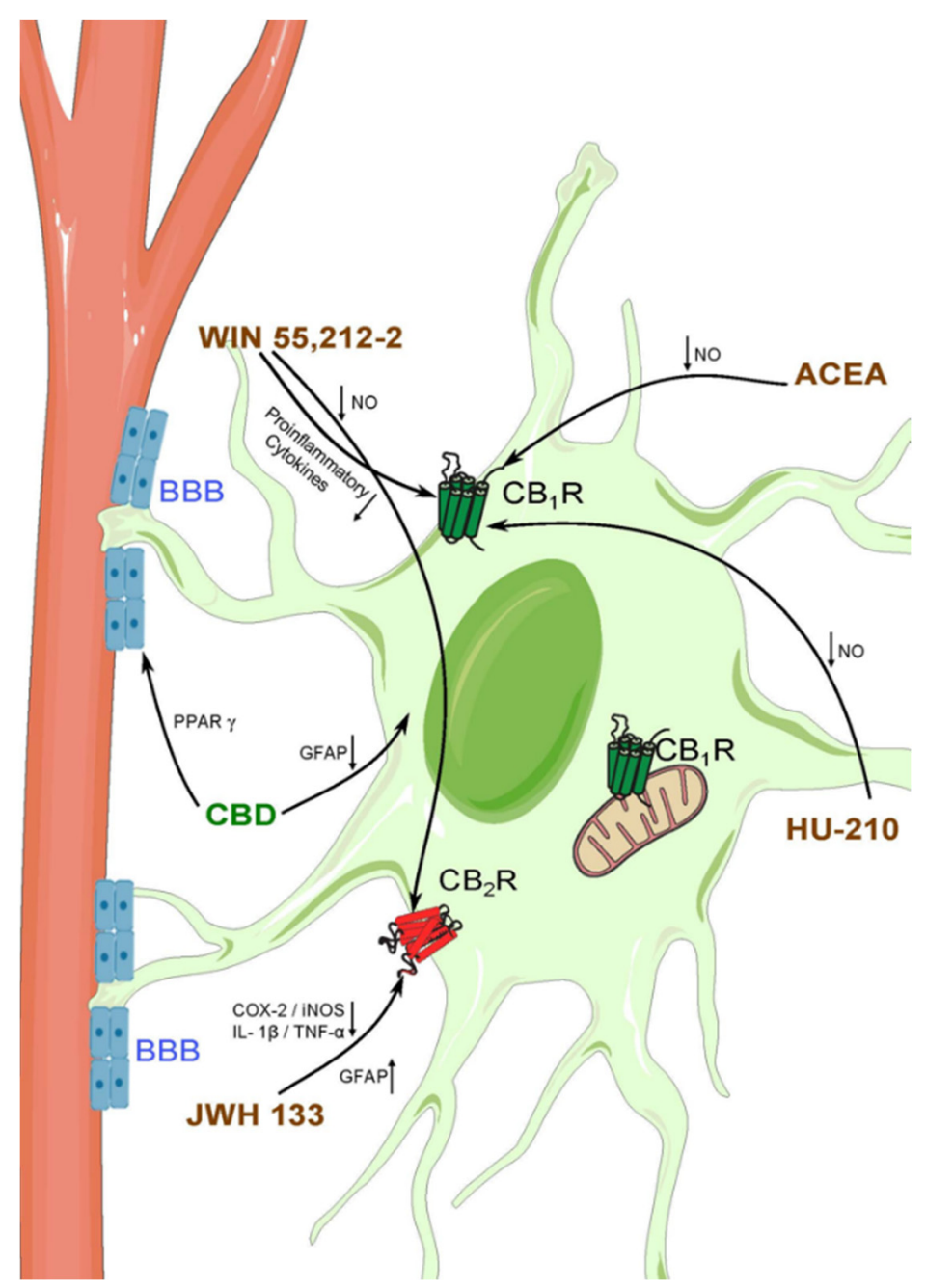

Figure 2. Schematic representation of the interactions of cannabinoid compounds with astrocytes in the context of epilepsy and neuroinflammation. Synthetic cannabinoids (brown) are able to interact with $\mathrm{CB}_{1}$ and $\mathrm{CB}_{2}$ receptors located in astrocytes. Moreover, some phytocannabinoids (green) modulate astrocyte functions on a cannabinoid-receptor-independent manner.

The synthetic cannabinoid arachidonyl-2'-chloroethylamide (ACEA) has anti-convulsant properties and shows interactions with various anti-epileptic drugs potentiating their effects in different epilepsy models [216-218]. Thus, ACEA-induced potentiation of valproic acid (VPA) increases newborn astrocytes in the hippocampus, suggesting a possible implication of the cannabinoid signaling in neurogenesis after epileptic insults [219]. Furthermore, the activation of $\mathrm{CB}_{1}$ Rs by ACEA and other synthetic cannabinoids (WIN55 212-2, HU-210) suppresses NO release in LPS-stimulated cultured astrocytes [121] (Figure 2), and WIN55 212-2 through $\mathrm{CB}_{1} \mathrm{R}$ and $\mathrm{CB}_{2} \mathrm{R}$ inhibits $\mathrm{NO}$ production and inflammatory molecules in astrocytic cultures [122] (Figure 2).

Epileptiform-like activity triggered by $\mathrm{Mg}^{+}$free medium in cortical astrocytic cultures, decreases $S$ phase but increases G1 phase astrocytes, suggesting that G1-S phase 
transition is disrupted during epilepsy [106]. Furthermore, the $\mathrm{CB}_{2} \mathrm{R}$ agonist JWH-133 upregulates $S$ phase astrocytes and increases GFAP expression (Figure 2). Interestingly, the enhanced astrocyte viability was mediated by PI3K-AKT signaling [106], a pathway that is dysregulated in several CNS disorders and epilepsy [220]. The JWH-133 also reduces the pro-inflammatory molecules COX-2, inducible nitric oxide synthase (iNOS), IL- $1 \beta$ and TNF $\alpha$ produced by 1-methyl-4-phenylpyridinium (MPP) in astrocyte primary cultures [221] (Figure 2). Furthermore, the neuronal damage caused by complement 3 (C3) in astrocytic cultures treated with 4-AP was significantly reduced in the absence of the vanilloid receptor TRPV1, suggesting that TRPV1 in astrocytes participates in the neuronal loss elicited in epilepsy models [117].

Over the last decades, experimental evidence points out a functional connection between neuroinflammation and ROS, and their participation in epileptogenesis $[11,222,223]$. The release of pro-inflammatory cytokines causes oxidative stress and exacerbates seizure generation [224]. However, both inflammation and ROS increase can be at the same time the cause and consequence of seizures [225]. Unlike neurons, energetic demand of astrocytes relies on glycolysis. Therefore, they produce more ROS that ultimately regulate neuronal survival by modulating glucose and brain redox [226]. Additionally, activation of $\mathrm{CB}_{1} \mathrm{Rs}$ localized in astrocytic mitochondria $[84,88]$ reduces mitochondrial soluble adenyl cyclase (AC) activity and PKA-dependent phosphorylation, decreasing complex I activity and mitochondrial ROS. Ultimately, mitochondrial $\mathrm{CB}_{1}$ Rs in astrocytes interfere with glucose metabolism and lactate production that affect neuronal functions and behavior [93]. Then, it is more than plausible that the $\mathrm{CB}_{1} \mathrm{R}$ located in astroglial mitochondria raises as a new potential target to treat seizures and reduce epileptogenesis. Further research is needed to elucidate this intriguing possibility.

\section{Oligodendroglia and ECS in Epilepsy}

\subsection{Oligodendrocytes}

Brain oligodendrocytes are less abundant than other glial cells, although their participation in cerebral physiology is essential [227]. Their main function is to produce myelin sheaths in the CNS, and drive remyelination processes after damage or in demyelinating disorders [228]. Nevertheless, these cells carry out other functions that contribute to neuronal functions and subsistence, such as a correct propagation of axon potentials or neurotrophic factor production [229].

The oligodendrocytes responsible for the mature myelin production are generated from the oligodendrocyte progenitor cells (OPC). The cells are distributed throughout certain regions in the CNS, being more abundant in the white matter (WM) $[230,231]$.

\subsection{Oligodendrocytes and Neuroinflammation}

The cognitive impairment observed in epileptic patients has been related to a reduced WM volume and abnormalities in gray matter (GM), as a consequence of the persistent inflammation that affects oligodendrocyte normal functioning and associates with oligondendrogliosis in the WM, even though the myelin content is decreased [232,233]. Due to the high metabolic rate, oligodendrocytes are much more sensitive to oxidative stress [229]. Furthermore, they are highly vulnerable to the neuroinflammation produced by cytokines released by microglia [234]. Oligodendrocytes also participate in the immune response as they can act as antigen-presenting cells, leading to the activation of CD8+ T cells [235]. They can also release inflammatory mediators resulting in microglia activation and express cytokine receptors, promoting microglial recruitment to damage sites [234]. Remarkably, blockade of LPS-stimulated pro-inflammatory molecules decreases oligondendrocytic loss and reduces WM impairment [236].

\subsection{Oligodendrocytes and ECS in Epilepsy}

Oligodendrocytes express both $\mathrm{CB}_{1}$ and $\mathrm{CB}_{2}$ receptors [237]. The ECS manipulation and cannabimimetic compounds modulate migration, proliferation, differentiation, and 
survival of OPCs $[237,238]$. Likewise, cannabinoids regulate differentiation and myelination in mature oligodendrocytes [239]. This pharmacological approach could help seizures management, as promoting these events could restore WM. Furthermore, CBD reduces apoptosis and ROS production in cultured OPCs exposed to LPS or interferon $\gamma(\operatorname{IFN} \gamma)$, which suggests the involvement of the endoplasmic reticulum stress pathway [240]. Additionally, the $\mathrm{CB}_{2} \mathrm{R}$ selective agonist $\beta$-caryophyllene, inhibits LPS-induced cytotoxicity and NO, ROS and TNF $\alpha$ disposal in cultured oligodendrocytes [241].

Despite existing few reports linking oligodendrocyte participation in epilepsy, the role of these glial cells in inflammatory processes could also contribute to understand the complexity of seizures. Moreover, bearing in mind that some cognitive impairment in epileptic patients relates to WM deterioration, the amelioration of these deficits with cannabinoids could also help in epilepsy treatment.

\section{Conclusions}

The subcellular dissection of the ECS is a promising target for managing several diseases, including epileptic-like disorders. Although little is known about the underlying molecular machinery implicated in the effects of cannabimimetic compounds in the control of seizures, their efficacy has been extensively observed in the last decade. Actually, CBD has proven to be efficacious as anti-convulsant in Lennox-Gastaut syndrome and Dravet syndrome [21,242]. Although the participation of neurons is undeniable, the involvement of glial cells seems more than plausible. Despite the fact that neurons are the primary cells affected by seizures due to the hyperexcitation unleashed, glial cells are those implicated in the inflammatory response triggered after status epilepticus, which also affects the progression and extension of the damage. Importantly, these cells also express cannabinoid receptors and are able to release eCBs. Additionally, CBD, other phytocannabinoids, and cannabinoid-based synthetic compounds are currently being investigated and used for treating anxiety [243,244], neurological [69] or psychiatric disorders [245], in addition to many others that do not only affect CNS cells, for instance, cancer, autoimmune, metabolic, or inflammation-related diseases [246-248].

Altogether, understanding how cannabinoid compounds act on glial cells might ease to better comprehend the pathophysiology of seizures and the brain itself, leading to a better knowledge of other brain disorders. Furthermore, the glial cannabinoid signaling and related molecular effectors might be regarded as novel targets in the management of seizure-like disorders in the near future.

Author Contributions: Original draft preparation J.E.-H.; writing and figures preparing J.E.-H., E.S.-G. and P.G.; conceptualization, reviewing and editing E.S.-G. and P.G. All authors have read and agreed to the published version of the manuscript.

Funding: This work was supported by the Basque Government (IT1230-19, to P.G.); MINECO/FEDER UE (SAF2015-65034-R, to P.G.); Ministry of Science and Innovation (PID2019-107548RBI00, to P.G.); Red de Trastornos Adictivos, Instituto de Salud Carlos III (ISC-III) and European Regional Development Funds-European Union (ERDF-EU, Investing in your future; RD16/0017/0012, to P.G.); J.E.-H. is a Postdoctoral Researcher contracted with funds of Red de Trastornos Adictivos, Instituto de Salud Carlos III (ISC-III) and European Regional Development Funds-European Union (ERDF-EU, Investing in your future; RD16/0017/0012), and the Basque Government (IT1230-19). E.S.-G. is funded by Ikerbasque and MINECO (PGC2018-093990-A-I00; MICIU/AEI/FEDER, UE).

Conflicts of Interest: The authors declare that the research was conducted in the absence of any commercial or financial relationships that could be construed as a potential conflict of interest.

\section{References}

1. Bhalla, D.; Godet, B.; Druet-Cabanac, M.; Preux, P.-M. Etiologies of epilepsy: A comprehensive review. Expert Rev. Neurother. 2011, 11, 861-876. [CrossRef]

2. Forthoffer, N.; Brissart, H.; Tyvaert, L.; Maillard, L. Long-term cognitive outcomes in patient with epilepsy. Rev. Neurol. 2020, 176, 448-455. [CrossRef] 
3. Dingledine, R.; Varvel, N.H.; Dudek, F.E. When and How Do Seizures Kill Neurons, and Is Cell Death Relevant to Epileptogenesis? Adv. Exp. Med. Biol. 2014, 813, 109-122. [CrossRef] [PubMed]

4. Tian, D.-S.; Peng, J.; Murugan, M.; Feng, L.-J.; Liu, J.-L.; Eyo, U.B.; Zhou, L.-J.; Mogilevsky, R.; Wang, W.; Wu, L.-J. Chemokine CCL2-CCR2 Signaling Induces Neuronal Cell Death via STAT3 Activation and IL-1 $\beta$ Production after Status Epilepticus. J. Neurosci. 2017, 37, 7878-7892. [CrossRef] [PubMed]

5. Thijs, R.D.; Surges, R.; O’Brien, T.J.; Sander, J.W. Epilepsy in adults. Lancet 2019, 393, 689-701. [CrossRef]

6. Blair, R.E.; Deshpande, L.S.; DeLorenzo, R.J. Endocannabinoids and epilepsy. In Cannabinoids in Neurologic and Mental Disease; Academic Press: Cambridge, MA, USA, 2015; pp. 125-172. [CrossRef]

7. Choi, J.; Koh, S. Role of Brain Inflammation in Epileptogenesis. Yonsei Med. J. 2008, 49, 1-18. [CrossRef]

8. Devinsky, O.; Vezzani, A.; Najjar, S.; De Lanerolle, N.C.; Rogawski, M.A. Glia and epilepsy: Excitability and inflammation. Trends Neurosci. 2013, 36, 174-184. [CrossRef] [PubMed]

9. Vezzani, A. Epilepsy and Inflammation in the Brain: Overview and Pathophysiology. Epilepsy Curr. 2014, 14, 3-7. [CrossRef] [PubMed]

10. Vezzani, A.; Viviani, B. Neuromodulatory properties of inflammatory cytokines and their impact on neuronal excitability. Neuropharmacology 2015, 96, 70-82. [CrossRef] [PubMed]

11. Aronica, E.; Mühlebner, A. Neuropathology of Epilepsy. In Handbook of Clinical Neurology; Elsevier: Amsterdam, The Netherlands, 2018; Volume 145, pp. 193-216. [CrossRef]

12. Klein, P.; Dingledine, R.; Aronica, E.; Bernard, C.; Blümcke, I.; Boison, D.; Brodie, M.J.; Brooks-Kayal, A.R.; Engel, J.; Forcelli, P.A.; et al. Commonalities in epileptogenic processes from different acute brain insults: Do they translate? Epilepsia 2018, 59, 37-66. [CrossRef]

13. Citraro, R.; Russo, E.; Leo, A.; Russo, R.; Avagliano, C.; Navarra, M.; Calignano, A.; De Sarro, G. Pharmacokineticpharmacodynamic influence of N-palmitoylethanolamine, arachidonyl-2'-chloroethylamide and WIN 55,212-2 on the anticonvulsant activity of antiepileptic drugs against audiogenic seizures in DBA/2 mice. Eur. J. Pharmacol. 2016, 791, 523-534. [CrossRef]

14. Alger, B.E. Seizing an Opportunity for the Endocannabinoid System. Epilepsy Curr. 2014, 14, 272-276. [CrossRef] [PubMed]

15. Blair, R.E.; Deshpande, L.S.; DeLorenzo, R.J. Cannabinoids: Is there a potential treatment role in epilepsy? Expert Opin. Pharmacother. 2015, 16, 1911-1914. [CrossRef] [PubMed]

16. Katona, I. Cannabis and Endocannabinoid Signaling in Epilepsy. In Endocannabinoids; Springer International Publishing: Berlin/Heidelberg, Germany, 2015; Volume 231, pp. 285-316. [CrossRef]

17. Marsicano, G.; Goodenough, S.; Monory, K.; Hermann, H.; Eder, M.; Cannich, A.; Azad, S.C.; Cascio, M.G.; Gutiérrez, S.O.; van der Stelt, M.; et al. CB1 Cannabinoid Receptors and On-Demand Defense Against Excitotoxicity. Science 2003, 302, 84-88. [CrossRef]

18. Monory, K.; Massa, F.; Egertová, M.; Eder, M.; Blaudzun, H.; Westenbroek, R.; Kelsch, W.; Jacob, W.; Marsch, R.; Ekker, M.; et al. The Endocannabinoid System Controls Key Epileptogenic Circuits in the Hippocampus. Neuron 2006, 51, 455-466. [CrossRef] [PubMed]

19. Monory, K.; Polack, M.; Remus, A.; Lutz, B.; Korte, M. Cannabinoid CB1 Receptor Calibrates Excitatory Synaptic Balance in the Mouse Hippocampus. J. Neurosci. 2015, 35, 3842-3850. [CrossRef] [PubMed]

20. Sugaya, Y.; Kano, M. Control of excessive neural circuit excitability and prevention of epileptic seizures by endocannabinoid signaling. Cell. Mol. Life Sci. 2018, 75, 2793-2811. [CrossRef]

21. Perucca, E. Cannabinoids in the Treatment of Epilepsy: Hard Evidence at Last? J. Epilepsy Res. 2017, 7, 61-76. [CrossRef] [PubMed]

22. Ambrogini, P.; Torquato, P.; Bartolini, D.; Albertini, M.C.; Lattanzi, D.; Di Palma, M.; Marinelli, R.; Betti, M.; Minelli, A.; Cuppini, R.; et al. Excitotoxicity, neuroinflammation and oxidant stress as molecular bases of epileptogenesis and epilepsy-derived neurodegeneration: The role of vitamin E. Biochim. Biophys. Acta Mol. Basis Dis. 2019, 1865, 1098-1112. [CrossRef] [PubMed]

23. Borowicz-Reutt, K.K.; Czuczwar, S.J. Role of oxidative stress in epileptogenesis and potential implications for therapy. Pharmacol. Rep. 2020, 72, 1218-1226. [CrossRef] [PubMed]

24. Sadanandan, N.; Saft, M.; Gonzales-Portillo, B.; Borlongan, C.V. Multipronged Attack of Stem Cell Therapy in Treating the Neurological and Neuropsychiatric Symptoms of Epilepsy. Front. Pharmacol. 2021, 12, 596287. [CrossRef]

25. Rao, G.; Mashkouri, S.; Aum, D.; Marcet, P.; Borlongan, C.V. Contemplating stem cell therapy for epilepsy-induced neuropsychiatric symptoms. Neuropsychiatr. Dis. Treat. 2017, 13, 585-596. [CrossRef]

26. Rosell-Valle, C.; Martínez-Losa, M.; Matas-Rico, E.; Castilla-Ortega, E.; Zambrana-Infantes, E.; Gómez-Conde, A.I.; Sánchez-Salido, L.; de Guevara-Miranda, D.L.; Pedraza, C.; Serrano-Castro, P.J.; et al. GABAergic deficits in absence of LPA1 receptor, associated anxiety-like and coping behaviors, and amelioration by interneuron precursor transplants into the dorsal hippocampus. Brain Struct. Funct. 2021, 226, 1479-1495. [CrossRef]

27. Lentini, C.; D’Orange, M.; Marichal, N.; Trottmann, M.-M.; Vignoles, R.; Foucault, L.; Verrier, C.; Massera, C.; Raineteau, O.; Conzelmann, K.-K.; et al. Reprogramming reactive glia into interneurons reduces chronic seizure activity in a mouse model of mesial temporal lobe epilepsy. Cell Stem Cell 2021, 28, 2104-2121.E10. [CrossRef]

28. Cattaneo, S.; Verlengia, G.; Marino, P.; Simonato, M.; Bettegazzi, B. NPY and Gene Therapy for Epilepsy: How, When,... and Y. Front. Mol. Neurosci. 2021, 13, 608001. [CrossRef] 
29. Noè, F.; Pool, A.-H.; Nissinen, J.; Gobbi, M.; Bland, R.; Rizzi, M.; Balducci, C.; Ferraguti, F.; Sperk, G.; During, M.J.; et al. Neuropeptide $Y$ gene therapy decreases chronic spontaneous seizures in a rat model of temporal lobe epilepsy. Brain 2008, 131, 1506-1515. [CrossRef] [PubMed]

30. Shan, W.; Mao, X.; Wang, X.; Hogan, R.E.; Wang, Q. Potential surgical therapies for drug-resistant focal epilepsy. CNS Neurosci. Ther. 2021, 27, 994-1011. [CrossRef] [PubMed]

31. Youngerman, B.E.; Save, A.V.; McKhann, G.M. Magnetic Resonance Imaging-Guided Laser Interstitial Thermal Therapy for Epilepsy: Systematic Review of Technique, Indications, and Outcomes. Neurosurgery 2020, 86, E366-E382. [CrossRef]

32. Dell, K.; Cook, M.J.; Maturana, M.I. Deep Brain Stimulation for Epilepsy: Biomarkers for Optimization. Curr. Treat. Options Neurol. 2019, 21, 47. [CrossRef] [PubMed]

33. Zhou, J.J.; Chen, T.; Farber, S.H.; Shetter, A.G.; Ponce, F.A. Open-loop deep brain stimulation for the treatment of epilepsy: A systematic review of clinical outcomes over the past decade (2008-present). Neurosurg. Focus 2018, 45, E5. [CrossRef]

34. Verrotti, A.; Iapadre, G.; Di Francesco, L.; Zagaroli, L.; Farello, G. Diet in the Treatment of Epilepsy: What We Know So Far. Nutrients 2020, 12, 2645. [CrossRef]

35. Cully, M. Drug development: Illuminated targets. Nature 2014, 511, S12-S13. [CrossRef]

36. Eisenstein, M. Neurobiology: Unrestrained excitement. Nature 2014, 511, S4-S6. [CrossRef]

37. Savage, N. Epidemiology: The complexities of epilepsy. Nature 2014, 511, S2-S3. [CrossRef]

38. Narain, C. Genetics: Complex expressions. Nature 2014, 511, S8-S9. [CrossRef] [PubMed]

39. Amini, E.; Rezaei, M.; Ibrahim, N.M.; Golpich, M.; Ghasemi, R.; Mohamed, Z.; Raymond, A.A.; Dargahi, L.; Ahmadiani, A. A Molecular Approach to Epilepsy Management: From Current Therapeutic Methods to Preconditioning Efforts. Mol. Neurobiol. 2015, 52, 492-513. [CrossRef] [PubMed]

40. Bates, K. Epilepsy: Current Evidence-Based Paradigms for Diagnosis and Treatment. Prim. Care Clin. Off. Pr. 2015, 42, 217-232. [CrossRef]

41. Gupta, R.; Appleton, R. Corticosteroids in the management of the paediatric epilepsies. Arch. Dis. Child. 2005, 90, 379-384. [CrossRef] [PubMed]

42. Hancock, E.C.; Osborne, J.P.; Edwards, S.W. Treatment of infantile spasms. Cochrane Database Syst. Rev. 2013, CD001770. [CrossRef]

43. Munckhof, B.V.D.; Van Dee, V.; Sagi, L.; Caraballo, R.H.; Veggiotti, P.; Liukkonen, E.; Loddenkemper, T.; Fernández, I.S.; Buzatu, M.; Bulteau, C.; et al. Treatment of electrical status epilepticus in sleep: A pooled analysis of 575 cases. Epilepsia 2015, 56, 1738-1746. [CrossRef]

44. Castro, P.J.S.; Muñoz, C.P.; Morillejo, E.A.; Méndez, M.J.M.; Nieto, B.B. Factores vinculados a la adhesión al tratamiento en pacientes con epilepsia refractaria y no refractaria. Rev. Neurol. 2011, 53, 721. [CrossRef]

45. Barker-Haliski, M.; White, H.S. Glutamatergic Mechanisms Associated with Seizures and Epilepsy. Cold Spring Harb. Perspect. Med. 2015, 5, a022863. [CrossRef] [PubMed]

46. Terrone, G.; Salamone, A.; Vezzani, A. Inflammation and Epilepsy: Preclinical Findings and Potential Clinical Translation. Curr. Pharm. Des. 2017, 23, 5569-5576. [CrossRef]

47. Eastman, C.L.; D'Ambrosio, R.; Ganesh, T. Modulating neuroinflammation and oxidative stress to prevent epilepsy and improve outcomes after traumatic brain injury. Neuropharmacology 2020, 172, 107907. [CrossRef] [PubMed]

48. Dey, A.; Kang, X.; Qiu, J.; Du, Y.; Jiang, J. Anti-Inflammatory Small Molecules To Treat Seizures and Epilepsy: From Bench to Bedside. Trends Pharmacol. Sci. 2016, 37, 463-484. [CrossRef]

49. Schartz, N.D.; Wyatt-Johnson, S.K.; Price, L.R.; Colin, S.A.; Brewster, A.L. Status epilepticus triggers long-lasting activation of complement $\mathrm{C} 1 \mathrm{q}-\mathrm{C} 3$ signaling in the hippocampus that correlates with seizure frequency in experimental epilepsy. Neurobiol. Dis. 2018, 109, 163-173. [CrossRef]

50. Nagib, M.M.; Yu, Y.; Jiang, J. Targeting prostaglandin receptor EP2 for adjunctive treatment of status epilepticus. Pharmacol. Ther. 2020, 209, 107504. [CrossRef] [PubMed]

51. Khaspekov, L.G.; Frumkina, L.E. Molecular mechanisms mediating involvement of glial cells in brain plastic remodeling in epilepsy. Biochemistry (Moscow) 2017, 82, 380-391. [CrossRef]

52. Hiragi, T.; Ikegaya, Y.; Koyama, R. Microglia after Seizures and in Epilepsy. Cells 2018, 7, 26. [CrossRef] [PubMed]

53. Patel, D.C.; Tewari, B.P.; Chaunsali, L.; Sontheimer, H. Neuron-glia interactions in the pathophysiology of epilepsy. Nat. Rev. Neurosci. 2019, 20, 282-297. [CrossRef] [PubMed]

54. Verhoog, Q.P.; Holtman, L.; Aronica, E.; Van Vliet, E.A. Astrocytes as Guardians of Neuronal Excitability: Mechanisms Underlying Epileptogenesis. Front. Neurol. 2020, 11, 591690. [CrossRef] [PubMed]

55. Wong, M. The role of glia in epilepsy, intellectual disability, and other neurodevelopmental disorders in tuberous sclerosis complex. J. Neurodev. Disord. 2019, 11, 1-9. [CrossRef]

56. Allen, N.J.; Lyons, D.A. Glia as architects of central nervous system formation and function. Science 2018, 362, 181-185. [CrossRef] [PubMed]

57. Vezzani, A.; French, J.; Bartfai, T.; Baram, T.Z. The role of inflammation in epilepsy. Nat. Rev. Neurol. 2011, 7, 31-40. [CrossRef]

58. Kim, S.Y.; Porter, B.E.; Friedman, A.; Kaufer, D. A potential role for glia-derived extracellular matrix remodeling in postinjury epilepsy. J. Neurosci. Res. 2016, 94, 794-803. [CrossRef] [PubMed] 
59. Bauer, J.; Becker, A.J.; Elyaman, W.; Peltola, J.; Rüegg, S.; Titulaer, M.J.; Varley, J.A.; Beghi, E. Innate and adaptive immunity in human epilepsies. Epilepsia 2017, 58, 57-68. [CrossRef]

60. Eyo, U.B.; Murugan, M.; Long-Jun, W. Microglia-Neuron Communication in Epilepsy Ukpong. Glia 2017, 65, 1-26. [CrossRef]

61. Rosch, R.; Burrows, D.R.W.; Jones, L.B.; Peters, C.H.; Ruben, P.; Samarut, É. Functional Genomics of Epilepsy and Associated Neurodevelopmental Disorders Using Simple Animal Models: From Genes, Molecules to Brain Networks. Front. Cell. Neurosci. 2019, 13, 556. [CrossRef]

62. Ilyasov, A.A.; Milligan, C.E.; Pharr, E.P.; Howlett, A.C. The Endocannabinoid System and Oligodendrocytes in Health and Disease. Front. Neurosci. 2018, 12, 733. [CrossRef] [PubMed]

63. Friedman, D.; French, J.A.; Maccarrone, M. Safety, efficacy, and mechanisms of action of cannabinoids in neurological disorders. Lancet Neurol. 2019, 18, 504-512. [CrossRef]

64. Szaflarski, J.P.; Bebin, E.M. Cannabis, cannabidiol, and epilepsy — From receptors to clinical response. Epilepsy Behav. 2014, 41, 277-282. [CrossRef]

65. Mechoulam, R. Cannabis and epilepsy. Epilepsy Behav. 2017, 70, 278-279. [CrossRef] [PubMed]

66. Rosenberg, E.C.; Patra, P.H.; Whalley, B.J. Therapeutic effects of cannabinoids in animal models of seizures, epilepsy, epileptogenesis, and epilepsy-related neuroprotection. Epilepsy Behav. 2017, 70, 319-327. [CrossRef]

67. Asth, L.; Iglesias, L.P.; De Oliveira, A.C.; Moraes, M.F.D.; Moreira, F.A. Exploiting cannabinoid and vanilloid mechanisms for epilepsy treatment. Epilepsy Behav. 2019, 121, 106832. [CrossRef]

68. Morano, A.; Fanella, M.; Albini, M.; Cifelli, P.; Palma, E.; Giallonardo, A.T.; Di Bonaventura, C. Cannabinoids in the Treatment of Epilepsy: Current Status and Future Prospects. Neuropsychiatr. Dis. Treat. 2020, 16, 381-396. [CrossRef] [PubMed]

69. Cristino, L.; Bisogno, T.; Di Marzo, V. Cannabinoids and the expanded endocannabinoid system in neurological disorders. Nat. Rev. Neurol. 2020, 16, 9-29. [CrossRef]

70. Silvestro, S.; Mammana, S.; Cavalli, E.; Bramanti, P.; Mazzon, E. Use of Cannabidiol in the Treatment of Epilepsy: Efficacy and Security in Clinical Trials. Molecules 2019, 24, 1459. [CrossRef]

71. Gaston, T.E.; Szaflarski, J.P. Cannabis for the Treatment of Epilepsy: An Update. Curr. Neurol. Neurosci. Rep. 2018, 18, 73. [CrossRef] [PubMed]

72. Guggenhuber, S.; Monory, K.; Lutz, B.; Klugmann, M. AAV Vector-Mediated Overexpression of CB1 Cannabinoid Receptor in Pyramidal Neurons of the Hippocampus Protects against Seizure-Induced Excitoxicity. PLoS ONE 2010, 5, e15707. [CrossRef] [PubMed]

73. Wallace, M.J.; Martin, B.R.; DeLorenzo, R.J. Evidence for a physiological role of endocannabinoids in the modulation of seizure threshold and severity. Eur. J. Pharmacol. 2002, 452, 295-301. [CrossRef]

74. Chen, Z.; Yu, S.; Q, H.C.; Zhu, Y.; Mix, E.; Winblad, B.; Ljunggren, H.-G.; Zhu, J. Kainic acid-induced excitotoxic hippocampal neurodegeneration in C57BL/ 6 mice: B cell and $\mathrm{T}$ cell subsets may contribute differently to the pathogenesis. Brain Behav. Immun. 2004, 18, 175-185. [CrossRef]

75. Ludanyi, A.; Erőss, L.; Czirják, S.; Vajda, J.; Halász, P.; Watanabe, M.; Palkovits, M.; Maglóczky, Z.; Freund, T.F.; Katona, I. Downregulation of the CB1 Cannabinoid Receptor and Related Molecular Elements of the Endocannabinoid System in Epileptic Human Hippocampus. J. Neurosci. 2008, 28, 2976-2990. [CrossRef] [PubMed]

76. Falenski, K.W.; Carter, D.S.; Harrison, A.J.; Martin, B.R.; Blair, R.E.; DeLorenzo, R.J. Temporal characterization of changes in hippocampal cannabinoid CB1 receptor expression following pilocarpine-induced status epilepticus. Brain Res. 2009, 1262, 64-72. [CrossRef] [PubMed]

77. Goffin, K.; Van Paesschen, W.; Van Laere, K. In vivo activation of endocannabinoid system in temporal lobe epilepsy with hippocampal sclerosis. Brain 2011, 134, 1033-1040. [CrossRef]

78. Karlócai, M.M.R.; Tóth, K.K.; Watanabe, M.; Ledent, C.; Juhász, G.; Freund, T.T.F.; Maglóczky, Z.Z. Redistribution of CB1 Cannabinoid Receptors in the Acute and Chronic Phases of Pilocarpine-Induced Epilepsy. PLoS ONE 2011, 6, e27196. [CrossRef]

79. Marsicano, G.; Lutz, B. Expression of the cannabinoid receptor CB1 in distinct neuronal subpopulations in the adult mouse forebrain. Eur. J. Neurosci. 1999, 11, 4213-4225. [CrossRef]

80. Katona, I.; Freund, T.F. Multiple Functions of Endocannabinoid Signaling in the Brain. Annu. Rev. Neurosci. 2012, 35, 529-558. [CrossRef] [PubMed]

81. Bénard, G.; Massa, F.; Puente, N.; Lourenço, J.; Bellocchio, L.; Soria-Gomez, E.; Matias, I.; Delamarre, A.; Metna-Laurent, M.; Cannich, A.; et al. Mitochondrial CB1 receptors regulate neuronal energy metabolism. Nat. Neurosci. 2012, 15, 558-564. [CrossRef] [PubMed]

82. Shu-Jung Hu, S.; Mackie, K. Distribution of the Endocannabinoid System in the Central Nervous System. In Handbook of Experimental Pharmacology; Springer: New York, NY, USA, 2015; Volume 231, pp. 59-93. [CrossRef]

83. Soria-Gomez, E.; Zottola, A.C.P.; Mariani, Y.; Desprez, T.; Barresi, M.; Río, I.B.-D.; Muguruza, C.; Le Bon-Jego, M.; Julio-Kalajzić, F.; Flynn, R.; et al. Subcellular specificity of cannabinoid effects in striatonigral circuits. Neuron 2021, 109, 1513-1526.e11. [CrossRef] [PubMed]

84. Río, I.B.; Puente, N.; Mimenza, A.; Ramos, A.; Serrano, M.; Lekunberri, L.; Gerrikagoitia, I.; Christie, B.R.; Nahirney, P.C.; Grandes, P. Acute $\Delta 9$-tetrahydrocannabinol prompts rapid changes in cannabinoid CB 1 receptor immunolabeling and subcellular structure in CA1 hippocampus of young adult male mice. J. Comp. Neurol. 2021, 529, 2332-2346. [CrossRef] 
85. Egaña-Huguet, J.; Río, I.B.-D.; Gómez-Urquijo, S.M.; Mimenza, A.; Saumell-Esnaola, M.; Borrega-Roman, L.; del Caño, G.G.; Sallés, J.; Puente, N.; Gerrikagoitia, I.; et al. The Absence of the Transient Receptor Potential Vanilloid 1 Directly Impacts on the Expression and Localization of the Endocannabinoid System in the Mouse Hippocampus. Front. Neuroanat. 2021, 15, 645940. [CrossRef] [PubMed]

86. Río, I.B.-D.; Puente, N.; Peñasco, S.; Rico, I.; Gutiérrez-Rodríguez, A.; Elezgarai, I.; Ramos-Uriarte, A.; Reguero, L.; Gerrikagoitia, I.; Christie, B.; et al. Adolescent ethanol intake alters cannabinoid type-1 receptor localization in astrocytes of the adult mouse hippocampus. Addict. Biol. 2019, 24, 182-192. [CrossRef]

87. Stella, N. Cannabinoid and cannabinoid-like receptors in microglia, astrocytes, and astrocytomas. Glia 2010, 58, 1017-1030. [CrossRef] [PubMed]

88. Gutiérrez-Rodríguez, A.; Puente, N.; Elezgarai, I.; Ruehle, S.; Lutz, B.; Reguero, L.; Gerrikagoitia, I.; Marsicano, G.; Grandes, P. Anatomical characterization of the cannabinoid CB1receptor in cell-type-specific mutant mouse rescue models. J. Comp. Neurol. 2017, 525, 302-318. [CrossRef] [PubMed]

89. Navarrete, M.; Araque, A. Endocannabinoids Mediate Neuron-Astrocyte Communication. Neuron 2008, 57, 883-893. [CrossRef] [PubMed]

90. Navarrete, M.; Araque, A. Endocannabinoids Potentiate Synaptic Transmission through Stimulation of Astrocytes. Neuron 2010, 68, 113-126. [CrossRef]

91. Araque, A.; Castillo, P.E.; Manzoni, O.J.; Tonini, R. Synaptic functions of endocannabinoid signaling in health and disease. Neuropharmacology 2017, 124, 13-24. [CrossRef]

92. Gutiérrez-Rodríguez, A.; Río, I.B.-D.; Puente, N.; Gómez-Urquijo, S.M.; Fontaine, C.; Huguet, J.E.; Elezgarai, I.; Ruehle, S.; Lutz, B.; Robin, L.M.; et al. Localization of the cannabinoid type-1 receptor in subcellular astrocyte compartments of mutant mouse hippocampus. Glia 2018, 66, 1417-1431. [CrossRef] [PubMed]

93. Jimenez-Blasco, D.; Busquets-Garcia, A.; Hebert-Chatelain, E.; Serrat, R.; Vicente-Gutierrez, C.; Ioannidou, C.; Gómez-Sotres, P.; Lopez-Fabuel, I.; Resch-Beusher, M.; Resel, E.; et al. Glucose metabolism links astroglial mitochondria to cannabinoid effects. Nature 2020, 583, 603-608. [CrossRef] [PubMed]

94. Stella, N. Endocannabinoid signaling in microglial cells. Neuropharmacology 2009, 56, 244-253. [CrossRef] [PubMed]

95. Waksman, Y.; Olson, J.M.; Carlisle, S.J.; Cabral, G.A. The central cannabinoid receptor (CB1) mediates inhibition of nitric oxide production by rat microglial cells. J. Pharmacol. Exp. Ther. 1999, 288, 1357-1366.

96. De Meij, J.; Alfanek, Z.; Morel, L.; Decoeur, F.; Leyrolle, Q.; Picard, K.; Carrier, M.; Aubert, A.; Séré, A.; Lucas, C.; et al. Microglial Cannabinoid Type 1 Receptor Regulates Brain Inflammation in a Sex-Specific Manner. Cannabis Cannabinoid Res. 2021. [CrossRef]

97. Carlisle, S.J.; Marciano-Cabral, F.; Staab, A.; Ludwick, C.; Cabral, G.A. Differential expression of the CB2 cannabinoid receptor by rodent macrophages and macrophage-like cells in relation to cell activation. Int. Immunopharmacol. 2001, 2, 69-82. [CrossRef]

98. Maccarrone, M.; Bab, I.; Bíró, T.; Cabral, G.A.; Dey, S.K.; Di Marzo, V.; Konje, J.C.; Kunos, G.; Mechoulam, R.; Pacher, P.; et al. Endocannabinoid signaling at the periphery: 50 years after THC. Trends Pharmacol. Sci. 2015, 36, 277-296. [CrossRef]

99. Tanaka, M.; Sackett, S.; Zhang, Y. Endocannabinoid Modulation of Microglial Phenotypes in Neuropathology. Front. Neurol. 2020, 11, 87. [CrossRef]

100. Stempel, A.V.; Stumpf, A.; Zhang, H.-Y.; Özdoğan, T.; Pannasch, U.; Theis, A.-K.; Otte, D.-M.; Wojtalla, A.; Rácz, I.; Ponomarenko, A.; et al. Cannabinoid Type 2 Receptors Mediate a Cell Type-Specific Plasticity in the Hippocampus. Neuron 2016, 90, 795-809. [CrossRef]

101. Zhang, H.-Y.; Gao, M.; Shen, H.; Bi, G.-H.; Yang, H.-J.; Liu, Q.-R.; Wu, J.; Gardner, E.L.; Bonci, A.; Xi, Z.-X. Expression of functional cannabinoid CB2receptor in VTA dopamine neurons in rats. Addict. Biol. 2017, 22, 752-765. [CrossRef]

102. Jordan, C.J.; Xi, Z.-X. Progress in brain cannabinoid CB2 receptor research: From genes to behavior. Neurosci. Biobehav. Rev. 2019, 98, 208-220. [CrossRef]

103. Yu, S.-J.; Reiner, D.; Shen, H.; Wu, K.-J.; Liu, Q.-R.; Wang, Y. Time-Dependent Protection of CB2 Receptor Agonist in Stroke. PLoS ONE 2015, 10, e0132487. [CrossRef] [PubMed]

104. Atwood, B.; Mackie, K. CB2: A cannabinoid receptor with an identity crisis. Br. J. Pharmacol. 2010, 160, 467-479. [CrossRef]

105. Dhopeshwarkar, A.; Mackie, K. CB2 Cannabinoid Receptors as a Therapeutic Target—What Does the Future Hold? Mol. Pharmacol. 2014, 86, 430-437. [CrossRef] [PubMed]

106. Cao, Q.; Liu, X.; Yang, F.; Wang, H. CB2R induces a protective response for epileptic seizure via the PI3K $110 \alpha-A K T$ signaling pathway. Exp. Ther. Med. 2018, 16, 4784-4790. [CrossRef] [PubMed]

107. Wu, Q.; Wang, H. The spatiotemporal expression changes of CB2R in the hippocampus of rats following pilocarpine-induced status epilepticus. Epilepsy Res. 2018, 148, 8-16. [CrossRef] [PubMed]

108. Shapiro, L.; Wong, J.C.; Escayg, A. Reduced cannabinoid 2 receptor activity increases susceptibility to induced seizures in mice. Epilepsia 2019, 60, 2359-2369. [CrossRef] [PubMed]

109. Ji, X.; Zeng, Y.; Wu, J. The $\mathrm{CB}_{2}$ Receptor as a Novel Therapeutic Target for Epilepsy Treatment. Int. J. Mol. Sci. 2021, $22,8961$. [CrossRef]

110. Van Der Stelt, M.; Di Marzo, V. Endovanilloids. Putative endogenous ligands of transient receptor potential vanilloid 1 channels. Eur. J. Biochem. 2004, 271, 1827-1834. [CrossRef] [PubMed]

111. Kreitzer, F.R.; Stella, N. The therapeutic potential of novel cannabinoid receptors. Pharmacol. Ther. 2009, 122, 83-96. [CrossRef] 
112. Iannotti, F.A.; Hill, C.L.; Leo, A.; Alhusaini, A.; Soubrane, C.; Mazzarella, E.; Russo, E.; Whalley, B.J.; Di Marzo, V.; Stephens, G.J. Nonpsychotropic Plant Cannabinoids, Cannabidivarin (CBDV) and Cannabidiol (CBD), Activate and Desensitize Transient Receptor Potential Vanilloid 1 (TRPV1) Channels in Vitro: Potential for the Treatment of Neuronal Hyperexcitability. ACS Chem. Neurosci. 2014, 5, 1131-1141. [CrossRef]

113. Tudurí, E.; López, M.; Diéguez, C.; Nadal, A.; Nogueiras, R. GPR55 and the regulation of glucose homeostasis. Int. J. Biochem. Cell Biol. 2017, 88, 204-207. [CrossRef]

114. Petrosino, S.; Di Marzo, V. The pharmacology of palmitoylethanolamide and first data on the therapeutic efficacy of some of its new formulations. Br. J. Pharmacol. 2017, 174, 1349-1365. [CrossRef]

115. Galiazzo, G.; Giancola, F.; Stanzani, A.; Fracassi, F.; Bernardini, C.; Forni, M.; Pietra, M.; Chiocchetti, R. Localization of cannabinoid receptors CB1, CB2, GPR55, and PPAR $\alpha$ in the canine gastrointestinal tract. Histochem. Cell Biol. 2018, 150, 187-205. [CrossRef]

116. Petrosino, S.; Moriello, A.S.; Cerrato, S.; Fusco, M.; Puigdemont, A.; De Petrocellis, L.; Di Marzo, V. The anti-inflammatory mediator palmitoylethanolamide enhances the levels of 2-arachidonoyl-glycerol and potentiates its actions at TRPV1 cation channels. Br. J. Pharmacol. 2016, 173, 1154-1162. [CrossRef] [PubMed]

117. Jiang, G.-T.; Shao, L.; Kong, S.; Zeng, M.-L.; Cheng, J.-J.; Chen, T.-X.; Han, S.; Yin, J.; Liu, W.-H.; He, X.-H.; et al. Complement C3 Aggravates Post-epileptic Neuronal Injury Via Activation of TRPV. Neurosci. Bull. 2021, 37, 1427-1440. [CrossRef] [PubMed]

118. von Widdern, J.C.; Hohmann, T.; Dehghani, F. Abnormal Cannabidiol Affects Production of Pro-Inflammatory Mediators and Astrocyte Wound Closure in Primary Astrocytic-Microglial Cocultures. Molecules 2020, 25, 496. [CrossRef]

119. Braun, M.; Khan, Z.T.; Khan, M.B.; Kumar, M.; Ward, A.; Achyut, B.R.; Arbab, A.S.; Hess, D.C.; Hoda, N.M.; Baban, B.; et al. Selective activation of cannabinoid receptor-2 reduces neuroinflammation after traumatic brain injury via alternative macrophage polarization. Brain Behav. Immun. 2017, 68, 224-237. [CrossRef] [PubMed]

120. Sahu, P.; Mudgal, J.; Arora, D.; Kinra, M.; Mallik, S.B.; Rao, C.M.; Pai, K.S.R.; Nampoothiri, M. Cannabinoid receptor 2 activation mitigates lipopolysaccharide-induced neuroinflammation and sickness behavior in mice. Psychopharmacology 2019, 236, 1829-1838. [CrossRef]

121. Molina-Holgado, F.; Molina-Holgado, E.; Guaza, C.; Rothwell, N.J. Role of CB1 and CB2 receptors in the inhibitory effects of cannabinoids on lipopolysaccharide-induced nitric oxide release in astrocyte cultures. J. Neurosci. Res. 2002, 67, 829-836. [CrossRef] [PubMed]

122. Sheng, W.S.; Hu, S.; Min, X.; Cabral, G.A.; Lokensgard, J.R.; Peterson, P.K. Synthetic cannabinoid WIN55,212-2 inhibits generation of inflammatory mediators by IL-1?-stimulated human astrocytes. Glia 2005, 49, 211-219. [CrossRef]

123. Nagarkatti, P.; Pandey, R.; Rieder, S.A.; Hegde, V.L.; Nagarkatti, M. Cannabinoids as novel anti-inflammatory drugs. Futur. Med. Chem. 2009, 1, 1333-1349. [CrossRef] [PubMed]

124. Hickman, S.; Izzy, S.; Sen, P.; Morsett, L.; El Khoury, J. Microglia in neurodegeneration. Nat. Neurosci. 2018, 21, 1359-1369. [CrossRef] [PubMed]

125. Valero, J.; Paris, I.; Sierra, A. Lifestyle Shapes the Dialogue between Environment, Microglia, and Adult Neurogenesis. ACS Chem. Neurosci. 2016, 7, 442-453. [CrossRef]

126. Hanamsagar, R.; Bilbo, S.D. Environment matters: Microglia function and dysfunction in a changing world. Curr. Opin. Neurobiol. 2017, 47, 146-155. [CrossRef] [PubMed]

127. Komorowska-Müller, J.A.; Schmöle, A.-C. CB2 Receptor in Microglia: The Guardian of Self-Control. Int. J. Mol. Sci. 2021, 22, 19. [CrossRef]

128. Kettenmann, H.; Kirchhoff, F.; Verkhratsky, A. Microglia: New Roles for the Synaptic Stripper. Neuron 2013, 77, 10-18. [CrossRef] [PubMed]

129. Sierra, A.; Beccari, S.; Diaz-Aparicio, I.; Encinas, J.M.; Comeau, S.; Tremblay, M.-E. Surveillance, Phagocytosis, and Inflammation: How Never-Resting Microglia Influence Adult Hippocampal Neurogenesis. Neural Plast. 2014, 2014, 1-15. [CrossRef] [PubMed]

130. Baalman, K.; Marin, M.A.; Ho, T.S.-Y.; Godoy, M.; Cherian, L.; Robertson, C.; Rasband, M.N. Axon Initial Segment-Associated Microglia. J. Neurosci. 2015, 35, 2283-2292. [CrossRef] [PubMed]

131. Clark, K.C.; Josephson, A.; Benusa, S.; Hartley, R.K.; Baer, M.; Thummala, S.; Joslyn, M.; Sword, B.A.; Elford, H.; Oh, U.; et al. Compromised axon initial segment integrity in EAE is preceded by microglial reactivity and contact. Glia 2016, 64, 1190-1209. [CrossRef]

132. Weinhard, L.; Di Bartolomei, G.; Bolasco, G.; Machado, P.; Schieber, N.L.; Neniskyte, U.; Exiga, M.; Vadisiute, A.; Raggioli, A.; Schertel, A.; et al. Microglia remodel synapses by presynaptic trogocytosis and spine head filopodia induction. Nat. Commun. 2018, 9, 1228. [CrossRef]

133. Rodríguez-Iglesias, N.; Sierra, A.; Valero, J. Rewiring of Memory Circuits: Connecting Adult Newborn Neurons With the Help of Microglia. Front. Cell Dev. Biol. 2019, 7, 24. [CrossRef]

134. Batchelor, P.E.; Porritt, M.J.; Martinello, P.; Parish, C.L.; Liberatore, G.T.; Donnan, G.A.; Howells, D.W. Macrophages and Microglia Produce Local Trophic Gradients That Stimulate Axonal Sprouting Toward but Not beyond the Wound Edge. Mol. Cell. Neurosci. 2002, 21, 436-453. [CrossRef] [PubMed]

135. Li, Q.; Barres, B.A. Microglia and macrophages in brain homeostasis and disease. Nat. Rev. Immunol. 2018, 18, 225-242. [CrossRef]

136. Liu, J.; Wang, F. Role of Neuroinflammation in Amyotrophic Lateral Sclerosis: Cellular Mechanisms and Therapeutic Implications. Front. Immunol. 2017, 8, 1005. [CrossRef] 
137. Gabrielli, M.; Battista, N.; Riganti, L.; Prada, I.; Antonucci, F.; Cantone, L.; Matteoli, M.; Maccarrone, M.; Verderio, C. Active endocannabinoids are secreted on extracellular membrane vesicles. EMBO Rep. 2015, 16, 213-220. [CrossRef] [PubMed]

138. Szepesi, Z.; Manouchehrian, O.; Bachiller, S.; Deierborg, T. Bidirectional Microglia-Neuron Communication in Health and Disease. Front. Cell. Neurosci. 2018, 12, 323. [CrossRef] [PubMed]

139. Liu, M.; Jiang, L.; Wen, M.; Ke, Y.; Tong, X.; Huang, W.; Chen, R. Microglia depletion exacerbates acute seizures and hippocampal neuronal degeneration in mouse models of epilepsy. Am. J. Physiol. Physiol. 2020, 319, C605-C610. [CrossRef]

140. Vezzani, A.; Fujinami, R.S.; White, H.S.; Preux, P.-M.; Blümcke, I.; Sander, J.; Löscher, W. Infections, inflammation and epilepsy. Acta Neuropathol. 2016, 131, 211-234. [CrossRef] [PubMed]

141. Di Sapia, R.; Zimmer, T.S.; Kebede, V.; Balosso, S.; Ravizza, T.; Sorrentino, D.; Castillo, M.A.M.; Porcu, L.; Cattani, F.; Ruocco, A.; et al. CXCL1-CXCR1/2 signaling is induced in human temporal lobe epilepsy and contributes to seizures in a murine model of acquired epilepsy. Neurobiol. Dis. 2021, 158, 105468. [CrossRef] [PubMed]

142. Facchinetti, F.; Del Giudice, E.; Furegato, S.; Passarotto, M.; Leon, A. Cannabinoids ablate release of TNF? in rat microglial cells stimulated with lypopolysaccharide. Glia 2003, 41, 161-168. [CrossRef] [PubMed]

143. McCoy, K.L.; Matveyeva, M.; Carlisle, S.J.; Cabral, G.A. Cannabinoid inhibition of the processing of intact lysozyme by macrophages: Evidence for CB2 receptor participation. J. Pharmacol. Exp. Ther. 1999, 289, 1620-1625. [PubMed]

144. Sugiura, T.; Kondo, S.; Kishimoto, S.; Miyashita, T.; Nakane, S.; Kodaka, T.; Suhara, Y.; Takayama, H.; Waku, K. Evidence That 2-Arachidonoylglycerol but Not N-Palmitoylethanolamine or Anandamide Is the Physiological Ligand for the Cannabinoid CB2 Receptorr. Comparison of the Agonistic Activities of Various Cannabinoid Receptor Ligands in HL-60 Cells. J. Biol. Chem. 2000, 275, 605-612. [CrossRef] [PubMed]

145. Zhang, J.; Hoffert, C.; Vu, H.K.; Groblewski, T.; Ahmad, S.; O’Donnell, D. Induction of CB2 receptor expression in the rat spinal cord of neuropathic but not inflammatory chronic pain models. Eur. J. Neurosci. 2003, 17, 2750-2754. [CrossRef]

146. Kasatkina, L.A.; Rittchen, S.; Sturm, E.M. Neuroprotective and Immunomodulatory Action of the Endocannabinoid System under Neuroinflammation. Int. J. Mol. Sci. 2021, 22, 5431. [CrossRef]

147. Espejo-Porras, F.; Fernández-Ruiz, J.; de Lago, E. Analysis of endocannabinoid receptors and enzymes in the post-mortem motor cortex and spinal cord of amyotrophic lateral sclerosis patients. Amyotroph. Lateral Scler. Front. Degener. 2018, 19, 377-386. [CrossRef]

148. Talarico, G.; Trebbastoni, A.; Bruno, G.; De Lena, C. Modulation of the Cannabinoid System: A New Perspective for the Treatment of the Alzheimer's Disease. Curr. Neuropharmacol. 2018, 17, 176-183. [CrossRef] [PubMed]

149. Guzmán, M.; Sanchez, C.; Galve-Roperh, I. Control of the cell survival/death decision by cannabinoids. J. Mol. Med. 2001, 78, 613-625. [CrossRef] [PubMed]

150. Benito, C.; Kim, W.-K.; Chavarría, I.; Hillard, C.J.; Mackie, K.; Tolón, R.M.; Williams, K.; Romero, J. A Glial Endogenous Cannabinoid System Is Upregulated in the Brains of Macaques with Simian Immunodeficiency Virus-Induced Encephalitis. J. Neurosci. 2005, 25, 2530-2536. [CrossRef]

151. Cabral, G.A.; Raborn, E.S.; Griffin, L.; Dennis, J.; Marciano-Cabral, F. CB2 receptors in the brain: Role in central immune function. Br. J. Pharmacol. 2008, 153, 240-251. [CrossRef] [PubMed]

152. Van Sickle, M.D.; Duncan, M.; Kingsley, P.J.; Mouihate, A.; Urbani, P.; Mackie, K.; Stella, N.; Makriyannis, A.; Piomelli, D.; Davison, J.S.; et al. Identification and Functional Characterization of Brainstem Cannabinoid CB 2 Receptors. Science 2005, 310, 329-332. [CrossRef] [PubMed]

153. Zhang, H.Y.; Gao, M.; Liu, Q.-R.; Bi, G.-H.; Li, X.; Yang, H.-J.; Gardner, E.L.; Wu, J.; Xi, Z.-X. Cannabinoid CB2receptors modulate midbrain dopamine neuronal activity and dopamine-related behavior in mice. Proc. Natl. Acad. Sci. USA 2014, 111, E5007-E5015. [CrossRef] [PubMed]

154. Reusch, N.; Ravichandran, K.A.; Olabiyi, B.F.; Komorowska-Müller, J.A.; Hansen, J.N.; Ulas, T.; Beyer, M.; Zimmer, A.; Schmöle, A.C. Cannabinoid receptor 2 is necessary to induce toll-like receptor-mediated microglial activation. Glia 2021, 70, 71-88. [CrossRef]

155. Ramírez, B.G.; Blázquez, C.; Del Pulgar, T.G.; Guzmán, M.; de Ceballos, M.L. Prevention of Alzheimer's Disease Pathology by Cannabinoids: Neuroprotection Mediated by Blockade of Microglial Activation. J. Neurosci. 2005, 25, 1904-1913. [CrossRef]

156. Eljaschewitsch, E.; Witting, A.; Mawrin, C.; Lee, T.; Schmidt, P.M.; Wolf, S.; Hoertnagl, H.; Raine, C.S.; Schneider-Stock, R.; Nitsch, R.; et al. The Endocannabinoid Anandamide Protects Neurons during CNS Inflammation by Induction of MKP-1 in Microglial Cells. Neuron 2006, 49, 67-79. [CrossRef] [PubMed]

157. Pellati, F.; Borgonetti, V.; Brighenti, V.; Biagi, M.; Benvenuti, S.; Corsi, L. Cannabis sativa L. and Nonpsychoactive Cannabinoids: Their Chemistry and Role against Oxidative Stress, Inflammation, and Cancer. BioMed Res. Int. 2018, 2018, 1-15. [CrossRef] [PubMed]

158. Holloman, B.L.; Nagarkatti, M.; Nagarkatti, P. Epigenetic Regulation of Cannabinoid-Mediated Attenuation of Inflammation and Its Impact on the Use of Cannabinoids to Treat Autoimmune Diseases. Int. J. Mol. Sci. 2021, 22, 7302. [CrossRef] [PubMed]

159. Tang, Y.; Wolk, B.; Kendall, D.A. Effects of a CB2 Subtype Selective Agonist ABK5-1 on Cytokine Production in Microglia. J. Cell. Signal. 2021, 2, 85-93. [CrossRef]

160. Mecha, M.; Feliu, A.; Carrillo-Salinas, F.J.; Rueda-Zubiaurre, A.; Ortega-Gutiérrez, S.; de Sola, R.G.; Guaza, C. Endocannabinoids drive the acquisition of an alternative phenotype in microglia. Brain Behav. Immun. 2015, 49, 233-245. [CrossRef] 
161. Hernangomez, M.; Carrillo-Salinas, F.J.; Mecha, M.; Correa, F.; Mestre, L.; Loria, F.; Feliu, A.; Docagne, F.; Guaza, C. Brain Innate Immunity in the Regulation of Neuroinflammation: Therapeutic Strategies by Modulating CD200-CD200R Interaction Involve the Cannabinoid System. Curr. Pharm. Des. 2014, 20, 4707-4722. [CrossRef]

162. Tay, T.L.; Savage, J.C.; Hui, C.W.; Bisht, K.; Tremblay, M.-È. Microglia across the lifespan: From origin to function in brain development, plasticity and cognition. J. Physiol. 2017, 595, 1929-1945. [CrossRef]

163. Malek, N.; Popiolek-Barczyk, K.; Mika, J.; Przewlocka, B.; Starowicz, K. Anandamide, Acting viaCB2Receptors, Alleviates LPS-Induced Neuroinflammation in Rat Primary Microglial Cultures. Neural Plast. 2015, 2015, 1-10. [CrossRef]

164. Guo, S.; Liu, Y.; Ma, R.; Li, J.; Su, B. Neuroprotective effect of endogenous cannabinoids on ischemic brain injury induced by the excess microglia-mediated inflammation. Am. J. Transl. Res. 2016, 8, 2631-2640.

165. Lu, H.-C.; Mackie, K. An Introduction to the Endogenous Cannabinoid System. Biol. Psychiatry 2016, 79, 516-525. [CrossRef] [PubMed]

166. Froger, N.; Orellana, J.A.; Cohen-Salmon, M.; Ezan, P.; Amigou, E.; Sãjez, J.C.; Giaume, C. Cannabinoids prevent the opposite regulation of astroglial connexin 43 hemichannels and gap junction channels induced by pro-inflammatory treatments. $J$. Neurochem. 2009, 111, 1383-1397. [CrossRef]

167. Spittau, B.; Wullkopf, L.; Zhou, X.; Rilka, J.; Pfeifer, D.; Krieglstein, K. Endogenous transforming growth factor-beta promotes quiescence of primary microglia in vitro. Glia 2013, 61, 287-300. [CrossRef]

168. Wen, J.; Ribeiro, R.; Tanaka, M.; Zhang, Y. Activation of CB2 receptor is required for the therapeutic effect of ABHD6 inhibition in experimental autoimmune encephalomyelitis. Neuropharmacology 2015, 99, 196-209. [CrossRef]

169. Kallendrusch, S.; Kremzow, S.; Nowicki, M.; Grabiec, U.; Winkelmann, R.; Benz, A.; Kraft, R.; Bechmann, I.; Dehghani, F.; Koch, M. The G Protein-Coupled Receptor 55 Ligandl- $\alpha$-Lysophosphatidylinositol Exerts Microglia-Dependent Neuroprotection After Excitotoxic Lesion. Glia 2013, 61, 1822-1831. [CrossRef] [PubMed]

170. Pietr, M.; Kozela, E.; Levy, R.; Rimmerman, N.; Lin, Y.H.; Stella, N.; Vogel, Z.; Juknat, A. Differential changes in GPR55 during microglial cell activation. FEBS Lett. 2009, 583, 2071-2076. [CrossRef] [PubMed]

171. Saliba, S.W.; Jauch, H.; Gargouri, B.; Keil, A.; Hurrle, T.; Volz, N.; Mohr, F.; Van Der Stelt, M.; Bräse, S.; Fiebich, B.L. Antineuroinflammatory effects of GPR55 antagonists in LPS-activated primary microglial cells. J. Neuroinflammation 2018, 15, 322. [CrossRef]

172. Yu, Y.; Li, L.; Nguyen, D.T.; Mustafa, S.M.; Moore, B.M.; Jiang, J. Inverse Agonism of Cannabinoid Receptor Type 2 Confers Anti-inflammatory and Neuroprotective Effects Following Status Epileptics. Mol. Neurobiol. 2020, 57, 2830-2845. [CrossRef] [PubMed]

173. Reiner, A.; Heldt, S.A.; Presley, C.S.; Guley, N.H.; Elberger, A.J.; Deng, Y.; D’Surney, L.; Rogers, J.T.; Ferrell, J.; Bu, W.; et al. Motor, Visual and Emotional Deficits in Mice after Closed-Head Mild Traumatic Brain Injury Are Alleviated by the Novel CB2 Inverse Agonist SMM-189. Int. J. Mol. Sci. 2015, 16, 758-787. [CrossRef]

174. Guley, N.M.; Del Mar, N.A.; Ragsdale, T.; Li, C.; Perry, A.M.; Moore, B.M.; Honig, M.G.; Reiner, A. Amelioration of visual deficits and visual system pathology after mild TBI with the cannabinoid type-2 receptor inverse agonist SMM-189. Exp. Eye Res. 2019, 182, 109-124. [CrossRef] [PubMed]

175. Presley, C.S.; Mustafa, S.M.; Abidi, A.H.; Moore, B.M. Synthesis and biological evaluation of $\left(3^{\prime}, 5^{\prime}\right.$-dichloro-2,6-dihydroxybiphenyl-4-yl)-aryl/alkyl-methanone selective CB2 inverse agonist. Bioorganic Med. Chem. 2015, 23, 5390-5401. [CrossRef]

176. Correa, F.; Hernangómez, M.; Mestre, L.; Loría, F.; Spagnolo, A.; Docagne, F.; Di Marzo, V.; Guaza, C. Anandamide enhances IL-10 production in activated microglia by targeting CB2receptors: Roles of ERK1/2, JNK, and NF-kB. Glia 2010, 58, 135-147. [CrossRef]

177. Pertwee, R.G. Endocannabinoids and Their Pharmacological Actions. In Endocannabinoids; Pertwee, R.G., Ed.; Springer: Berlin, Germany, 2015; Volume 231, pp. 1-37. [CrossRef]

178. Mounsey, R.B.; Mustafa, S.; Robinson, L.; Ross, R.A.; Riedel, G.; Pertwee, R.G.; Teismann, P. Increasing levels of the endocannabinoid 2-AG is neuroprotective in the 1-methyl-4-phenyl-1,2,3,6-tetrahydropyridine mouse model of Parkinson's disease. Exp. Neurol. 2015, 273, 36-44. [CrossRef]

179. Kreutz, S.; Koch, M.; Ghadban, C.; Korf, H.W.; Dehghani, F. Cannabinoids and neuronal damage: Differential effects of THC, AEA and 2-AG on activated microglial cells and degenerating neurons in excitotoxically lesioned rat organotypic hippocampal slice cultures. Exp. Neurol. 2007, 203, 246-257. [CrossRef] [PubMed]

180. Koch, M.; Kreutz, S.; Böttger, C.; Benz, A.; Maronde, E.; Ghadban, C.; Korf, H.-W.; Dehghani, F. Palmitoylethanolamide Protects Dentate Gyrus Granule Cells via Peroxisome Proliferator-Activated Receptor-Alpha. Neurotox. Res. 2011, 19, 330-340. [CrossRef]

181. Kreutz, S.; Koch, M.; Böttger, C.; Ghadban, C.; Korf, H.-W.; Dehghani, F. 2-Arachidonoylglycerol elicits neuroprotective effects on excitotoxically lesioned dentate gyrus granule cells via abnormal-cannabidiol-sensitive receptors on microglial cells. Glia 2009, 57, 286-294. [CrossRef]

182. Offertáler, L.; Mo, F.-M.; Bátkai, S.; Liu, J.; Begg, M.; Razdan, R.K.; Martin, B.R.; Bukoski, R.D.; Kunos, G. Selective Ligands and Cellular Effectors of a G Protein-Coupled Endothelial Cannabinoid Receptor. Mol. Pharmacol. 2003, 63, 699-705. [CrossRef]

183. Begg, M.; Mo, F.-M.; Offertáler, L.; Bátkai, S.; Pacher, P.; Razdan, R.K.; Lovinger, D.M.; Kunos, G. G Protein-coupled Endothelial Receptor for Atypical Cannabinoid Ligands Modulates a Ca2+-dependent K+ Current. J. Biol. Chem. 2003, 278, 46188-46194. [CrossRef] [PubMed]

184. Lutz, B.; Monory, K. Bench to Bedside: Soothing the seizures of children. Nat. Med. 2008, 14, 721-722. [CrossRef] 
185. Citraro, R.; Russo, E.; Scicchitano, F.; van Rijn, C.M.; Cosco, D.; Avagliano, C.; Russo, R.; D’Agostino, G.; Petrosino, S.; Guida, F.; et al. Antiepileptic action of N-palmitoylethanolamine through CB1 and PPAR- $\alpha$ receptor activation in a genetic model of absence epilepsy. Neuropharmacology 2013, 69, 115-126. [CrossRef]

186. Aghaei, I.; Rostampour, M.; Shabani, M.; Naderi, N.; Motamedi, F.; Babaei, P.; Khakpour-Taleghani, B. Palmitoylethanolamide attenuates PTZ-induced seizures through CB1 and CB2 receptors. Epilepsy Res. 2015, 117, 23-28. [CrossRef] [PubMed]

187. Warden, A.; Truitt, J.; Merriman, M.; Ponomareva, O.; Jameson, K.; Ferguson, L.B.; Mayfield, R.D.; Harris, R.A. Localization of PPAR isotypes in the adult mouse and human brain. Sci. Rep. 2016, 6, 27618. [CrossRef]

188. Guida, F.; Luongo, L.; Boccella, S.; Giordano, M.E.; Romano, R.; Bellini, G.; Manzo, I.; Furiano, A.; Rizzo, A.; Imperatore, R.; et al. Palmitoylethanolamide induces microglia changes associated with increased migration and phagocytic activity: Involvement of the CB2 receptor. Sci. Rep. 2017, 7, 375. [CrossRef]

189. Musella, A.; Fresegna, D.; Rizzo, F.R.; Gentile, A.; Bullitta, S.; De Vito, F.; Guadalupi, L.; Centonze, D.; Mandolesi, G. A novel crosstalk within the endocannabinoid system controls GABA transmission in the striatum. Sci. Rep. 2017, 7, 7363. [CrossRef]

190. Hohmann, U.; Pelzer, M.; Kleine, J.; Hohmann, T.; Ghadban, C.; Dehghani, F. Opposite Effects of Neuroprotective Cannabinoids, Palmitoylethanolamide, and 2-Arachidonoylglycerol on Function and Morphology of Microglia. Front. Neurosci. 2019, 13, 1180. [CrossRef] [PubMed]

191. Sonego, A.B.; Prado, D.S.; Vale, G.T.; Sepulveda-Diaz, J.E.; Cunha, T.M.; Tirapelli, C.R.; Del Bel, E.A.; Raisman-Vozari, R.; Guimarães, F.S. Cannabidiol prevents haloperidol-induced vacuos chewing movements and inflammatory changes in mice via PPAR $\gamma$ receptors. Brain Behav. Immun. 2018, 74, 241-251. [CrossRef]

192. Chung, W.-S.; Welsh, C.A.; Barres, B.A.; Stevens, B. Do glia drive synaptic and cognitive impairment in disease? Nat. Neurosci. 2015, 18, 1539-1545. [CrossRef] [PubMed]

193. Sardinha, V.M.; Guerra-Gomes, S.; Caetano, I.; Tavares, G.; Martins, M.; Reis, J.S.; Correia, J.S.; Teixeira-Castro, A.; Pinto, L.; Sousa, N.; et al. Astrocytic signaling supports hippocampal-prefrontal theta synchronization and cognitive function. Glia 2017, 65, 1944-1960. [CrossRef]

194. Adamsky, A.; Kol, A.; Kreisel, T.; Doron, A.; Ozeri-Engelhard, N.; Melcer, T.; Refaeli, R.; Horn, H.; Regev, L.; Groysman, M.; et al. Astrocytic Activation Generates De Novo Neuronal Potentiation and Memory Enhancement. Cell 2018, 174, 59-71.e14. [CrossRef]

195. Santello, M.; Toni, N.; Volterra, A. Astrocyte function from information processing to cognition and cognitive impairment. Nat. Neurosci. 2019, 22, 154-166. [CrossRef] [PubMed]

196. MacVicar, B.A.; Newman, E.A. Astrocyte Regulation of Blood Flow in the Brain. Cold Spring Harb. Perspect. Biol. 2015, 7, a020388. [CrossRef]

197. Araque, A.; Parpura, V.; Sanzgiri, R.P.; Haydon, P.G. Tripartite synapses: Glia, the unacknowledged partner. Trends Neurosci. 1999, 22, 208-215. [CrossRef]

198. Perea, G.; Navarrete, M.; Araque, A. Tripartite synapses: Astrocytes process and control synaptic information. Trends Neurosci. 2009, 32, 421-431. [CrossRef]

199. Volterra, A.; Liaudet, N.; Savtchouk, I. Astrocyte $\mathrm{Ca}^{2+}$ signalling: An unexpected complexity. Nat. Rev. Neurosci. 2014, 15, 327-335. [CrossRef]

200. Coulter, D.A.; Eid, T. Astrocytic regulation of glutamate homeostasis in epilepsy. Glia 2012, 60, 1215-1226. [CrossRef] [PubMed]

201. Araque, A.; Carmignoto, G.; Haydon, P.G.; Oliet, S.H.R.; Robitaille, R.; Volterra, A. Gliotransmitters Travel in Time and Space. Neuron 2014, 81, 728-739. [CrossRef]

202. Coulter, D.A.; Steinhäuser, C. Role of Astrocytes in Epilepsy. Cold Spring Harb. Perspect. Med. 2015, 5, a022434. [CrossRef] [PubMed]

203. Pekny, M.; Pekna, M.; Messing, A.; Steinhäuser, C.; Lee, J.-M.; Parpura, V.; Hol, E.M.; Sofroniew, M.V.; Verkhratsky, A. Astrocytes: A central element in neurological diseases. Acta Neuropathol. 2016, 131, 323-345. [CrossRef]

204. Kardos, J.; Héja, L.; Jemnitz, K.; Kovacs, R.; Palkovits, M. The nature of early astroglial protection-Fast activation and signaling. Prog. Neurobiol. 2017, 153, 86-99. [CrossRef]

205. Kozela, E.; Juknat, A.; Vogel, Z. Modulation of Astrocyte Activity by Cannabidiol, a Nonpsychoactive Cannabinoid. Int. J. Mol. Sci. 2017, 18, 1669. [CrossRef]

206. Boison, D. Adenosine dysfunction in epilepsy. Glia 2012, 60, 1234-1243. [CrossRef]

207. Dulla, C.G. Losing Touch with Your Astrocytes Can Cause Epilepsy. Epilepsy Curr. 2015, 15, 349-350. [CrossRef]

208. Boison, D.; Steinhäuser, C. Epilepsy and astrocyte energy metabolism. Glia 2018, 66, 1235-1243. [CrossRef]

209. Bedner, P.; Steinhäuser, C. Neuron-glia interaction in epilepsy. J. Neurosci. Res. 2016, 94, 779-780. [CrossRef]

210. Steinhäuser, C.; Grunnet, M.; Carmignoto, G. Crucial role of astrocytes in temporal lobe epilepsy. Neuroscience 2016, 323, 157-169. [CrossRef] [PubMed]

211. Navarrete, M.; Díez, A.; Araque, A. Astrocytes in endocannabinoid signalling. Philos. Trans. R. Soc. B Biol. Sci. 2014, $369,20130599$. [CrossRef] [PubMed]

212. Meng, X.-D.; Wei, D.; Li, J.; Kang, J.-J.; Wu, C.; Ma, L.; Yang, F.; Zhu, G.-M.; Ou-Yang, T.-P.; Liu, Y.-Y.; et al. Astrocytic expression of cannabinoid type 1 receptor in rat and human sclerotic hippocampi. Int. J. Clin. Exp. Pathol. 2014, 7, $2825-2837$.

213. Coiret, G.; Ster, J.; Grewe, B.; Wendling, F.; Helmchen, F.; Gerber, U.; Benquet, P. Neuron to Astrocyte Communication via Cannabinoid Receptors Is Necessary for Sustained Epileptiform Activity in Rat Hippocampus. PLoS ONE 2012, 7, e37320. [CrossRef] 
214. Mao, K.; You, C.; Lei, D.; Zhang, H. High dosage of cannabidiol (CBD) alleviates pentylenetetrazole-induced epilepsy in rats by exerting an anticonvulsive effect. Int. J. Clin. Exp. Med. 2015, 8, 8820-8827. [PubMed]

215. Hind, W.H.; England, T.J.; O'Sullivan, S.E. Cannabidiol protects an in vitro model of the blood-brain barrier from oxygen-glucose deprivation via PPAR $\gamma$ and 5-HT1A receptors. Br. J. Pharmacol. 2016, 173, 815-825. [CrossRef] [PubMed]

216. Luszczki, J.J.; Czuczwar, P.; Cioczek-Czuczwar, A.; Czuczwar, S.J. Arachidonyl-2'-chloroethylamide, a highly selective cannabinoid CB1 receptor agonist, enhances the anticonvulsant action of valproate in the mouse maximal electroshock-induced seizure model. Eur. J. Pharmacol. 2006, 547, 65-74. [CrossRef] [PubMed]

217. Andres-Mach, M.; Zolkowska, D.; Barcicka-Klosowska, B.; Haratym-Maj, A.; Florek-Łuszczki, M.; Luszczki, J.J. Effect of ACEA - a selective cannabinoid CB1 receptor agonist on the protective action of different antiepileptic drugs in the mouse pentylenetetrazole-induced seizure model. Prog. Neuro-Psychopharmacol. Biol. Psychiatry 2012, 39, 301-309. [CrossRef] [PubMed]

218. Naderi, N.; Ahmad-Molaei, L.; Mazar-Atabaki, A.; Ronaghi, A.; Shirazi-Zand, Z.; Motiei-Langroudi, S.M.; Eslahkar, S. L-Type Calcium Channel Mediates Anticonvulsant Effect of Cannabinoids in Acute and Chronic Murine Models of Seizure. Neurochem. Res. 2012, 37, 279-287. [CrossRef] [PubMed]

219. Andres-Mach, M.; Zagaja, M.; Haratym-Maj, A.; Rola, R.; Maj, M.; Haratym, J.; Dudra-Jastrzębska, M.; Łuszczki, J.J. A Long-Term Treatment with Arachidonyl-2'-Chloroethylamide Combined with Valproate Increases Neurogenesis in a Mouse Pilocarpine Model of Epilepsy. Int. J. Mol. Sci. 2017, 18, 900. [CrossRef]

220. Roy, A.; Skibo, J.; Kalume, F.; Ni, J.; Rankin, S.; Lu, Y.; Dobyns, W.B.; Mills, G.B.; Zhao, J.J.; Baker, S.J.; et al. Mouse models of human PIK3CA-related brain overgrowth have acutely treatable epilepsy. eLife 2015, 4, e12703. [CrossRef]

221. Jia, Y.; Deng, H.; Qin, Q.; Ma, Z.G. JWH133 inhibits MPP+-induced inflammatory response and iron influx in astrocytes. Neurosci. Lett. 2020, 720, 134779. [CrossRef] [PubMed]

222. de Vries, E.E.; van den Munckhof, B.; Braun, K.P.J.; van Royen-Kerkhof, A.; de Jager, W.; Jansen, F.E. Inflammatory mediators in human epilepsy: A systematic review and meta-analysis. Neurosci. Biobehav. Rev. 2016, 63, 177-190. [CrossRef]

223. Pearson-Smith, J.N.; Patel, M. Metabolic Dysfunction and Oxidative Stress in Epilepsy. Int. J. Mol. Sci. 2017, 18, 2365. [CrossRef] [PubMed]

224. Bhuyan, P.; Patel, D.C.; Wilcox, K.S.; Patel, M. Oxidative stress in murine Theiler's virus-induced temporal lobe epilepsy. Exp. Neurol. 2015, 271, 329-334. [CrossRef]

225. Patel, M. Mitochondrial dysfunction and oxidative stress: Cause and consequence of epileptic seizures. Free. Radic. Biol. Med. 2004, 37, 1951-1962. [CrossRef]

226. Vicente-Gutierrez, C.; Bonora, N.; Bobo-Jimenez, V.; Jimenez-Blasco, D.; Lopez-Fabuel, I.; Fernandez, E.; Josephine, C.; Bonvento, G.; Enriquez, J.A.; Almeida, A.; et al. Astrocytic mitochondrial ROS modulate brain metabolism and mouse behaviour. Nat. Metab. 2019, 1, 201-211. [CrossRef]

227. Bradl, M.; Lassmann, H. Oligodendrocytes: Biology and pathology. Acta Neuropathol. 2010, 119, 37-53. [CrossRef]

228. Franklin, R.J.M.; Ffrench-Constant, C. Regenerating CNS myelin-From mechanisms to experimental medicines. Nat. Rev. Neurosci. 2017, 18, 753-769. [CrossRef] [PubMed]

229. Peferoen, L.; Kipp, M.; Van Der Valk, P.; van Noort, J.M.; Amor, S. Oligodendrocyte-microglia cross-talk in the central nervous system. Immunology 2014, 141, 302-313. [CrossRef]

230. Kuhn, S.; Gritti, L.; Crooks, D.; Dombrowski, Y. Oligodendrocytes in Development, Myelin Generation and Beyond. Cells 2019, 8, 1424. [CrossRef] [PubMed]

231. Navarrete, C.; García-Martín, A.; Rolland, A.; DeMesa, J.; Muñoz, E. Cannabidiol and Other Cannabinoids in Demyelinating Diseases. Int. J. Mol. Sci. 2021, 22, 2992. [CrossRef] [PubMed]

232. Rodríguez-Cruces, R.; Concha, L. White matter in temporal lobe epilepsy: Clinico-pathological correlates of water diffusion abnormalities. Quant. Imaging Med. Surg. 2015, 5, 264-278. [CrossRef]

233. Beheshti, I.; Sone, D.; Farokhian, F.; Maikusa, N.; Matsuda, H. Gray Matter and White Matter Abnormalities in Temporal Lobe Epilepsy Patients with and without Hippocampal Sclerosis. Front. Neurol. 2018, 9, 107. [CrossRef]

234. Kölliker-Frers, R.; Udovin, L.; Otero-Losada, M.; Kobiec, T.; Herrera, M.I.; Palacios, J.; Razzitte, G.; Capani, F. Neuroinflammation: An Integrating Overview of Reactive-Neuroimmune Cell Interactions in Health and Disease. Mediat. Inflamm. 2021, 2021, 1-20. [CrossRef]

235. Kalafatakis, I.; Karagogeos, D. Oligodendrocytes and Microglia: Key Players in Myelin Development, Damage and Repair. Biomolecules 2021, 11, 1058. [CrossRef]

236. Kelly, S.B.; Stojanovska, V.; Zahra, V.A.; Moxham, A.; Miller, S.L.; Moss, T.J.M.; Hooper, S.B.; Nold, M.F.; Nold-Petry, C.A.; Dean, J.M.; et al. Interleukin-1 blockade attenuates white matter inflammation and oligodendrocyte loss after progressive systemic lipopolysaccharide exposure in near-term fetal sheep. J. Neuroinflamm. 2021, 18, 1-18. [CrossRef] [PubMed]

237. Molina-Holgado, E.; Vela, J.M.; Arevalo-Martin, A.; Almazán, G.; Molina-Holgado, F.; Borrell, J.; Guaza, C. Cannabinoids Promote Oligodendrocyte Progenitor Survival: Involvement of Cannabinoid Receptors and Phosphatidylinositol-3 Kinase/Akt Signaling. J. Neurosci. 2002, 22, 9742-9753. [CrossRef] [PubMed]

238. Sun, J.; Fang, Y.; Chen, T.; Guo, J.; Yan, J.; Song, S.; Zhang, L.; Liao, H. WIN55, 212-2 promotes differentiation of oligodendrocyte precursor cells and improve remyelination through regulation of the phosphorylation level of the ERK 1/2 via cannabinoid receptor 1 after stroke-induced demyelination. Brain Res. 2013, 1491, 225-235. [CrossRef] 
239. Tomas-Roig, J.; Wirths, O.; Salinas-Riester, G.; Havemann-Reinecke, U. The Cannabinoid CB1/CB2 Agonist WIN55212.2 Promotes Oligodendrocyte Differentiation In Vitro and Neuroprotection During the Cuprizone-Induced Central Nervous System Demyelination. CNS Neurosci. Ther. 2016, 22, 387-395. [CrossRef] [PubMed]

240. Mecha, M.; Torrão, A.S.; Mestre, L.; Carrillo-Salinas, F.J.; Mechoulam, R.; Guaza, C. Cannabidiol protects oligodendrocyte progenitor cells from inflammation-induced apoptosis by attenuating endoplasmic reticulum stress. Cell Death Dis. 2012, 3, e331. [CrossRef]

241. Askari, V.R.; Shafiee-Nick, R. Promising neuroprotective effects of $\beta$-caryophyllene against LPS-induced oligodendrocyte toxicity: A mechanistic study. Biochem. Pharmacol. 2019, 159, 154-171. [CrossRef]

242. Devinsky, O.; Thiele, E.A.; Wright, S.; Checketts, D.; Morrison, G.; Dunayevich, E.; Knappertz, V. Cannabidiol efficacy independent of clobazam: Meta-analysis of four randomized controlled trials. Acta Neurol. Scand. 2020, 142, 531-540. [CrossRef]

243. Sarris, J.; Mc Intyre, E.; Camfield, D.A. Plant-Based Medicines for Anxiety Disorders, Part 2: A Review of Clinical Studies with Supporting Preclinical Evidence. CNS Drugs 2013, 27, 301-319. [CrossRef] [PubMed]

244. Breuer, A.; Haj, C.G.; Fogaça, M.V.; Gomes, F.V.; Silva, N.R.; Pedrazzi, J.F.; Del Bel, E.A.; Hallak, J.C.; Crippa, J.A.; Zuardi, A.W.; et al. Fluorinated Cannabidiol Derivatives: Enhancement of Activity in Mice Models Predictive of Anxiolytic, Antidepressant and Antipsychotic Effects. PLoS ONE 2016, 11, e0158779. [CrossRef]

245. Mandolini, G.M.; Lazzaretti, M.; Pigoni, A.; Oldani, L.; Delvecchio, G.; Brambilla, P. Pharmacological properties of cannabidiol in the treatment of psychiatric disorders: A critical overview. Epidemiol. Psychiatr. Sci. 2018, 27, 327-335. [CrossRef] [PubMed]

246. Pacher, P.; Kogan, N.M.; Mechoulam, R. Beyond THC and Endocannabinoids. Annu. Rev. Pharmacol. Toxicol. 2020, 60, 637-659. [CrossRef] [PubMed]

247. Śledziński, P.; Nowak-Terpiłowska, A.; Zeyland, J. Cannabinoids in Medicine: Cancer, Immunity, and Microbial Diseases. Int. J. Mol. Sci. 2020, 22, 263. [CrossRef]

248. Morales, P.; Reggio, P.H. Emerging Roles of Cannabinoids and Synthetic Cannabinoids in Clinical Experimental Models. Adv. Exp. Med. Biol. 2021, 1264, 47-65. [CrossRef] [PubMed] 